\title{
A PERCEPÇÃO E A ACEITABILIDADE DE FORMAS DE TRATAMENTO NO PORTUGUÊS EUROPEU (PE): UMA ABORDAGEM EXPERIMENTAL
}

\author{
THE PERCEPTION AND ACCEPTABILITY \\ OF ADDRESS FORMS IN EUROPEAN PORTUGUESE (EP): \\ AN EXPERIMENTAL APPROACH
}

Célia Regina Lopes | Lattes | celiar.s.lopes@gmail.com Universidade Federal do Rio de Janeiro

\author{
Maria Antónia Mota | CV \\ Universidade de Lisboa
}

Resumo: O objetivo do trabalho é apresentar os resultados de um experimento realizado em Lisboa para detectar o valor social assumido pelas variantes tu e você no português europeu. Um teste de julgamento de aceitabilidade das formas de segunda pessoa em variação na posição de sujeito foi realizado com 34 participantes portugueses seguindo o modelo realizado por Oliveira, Lopes e Carvalho (2016) com falantes do Rio de Janeiro. $\mathrm{O}$ objetivo do experimento foi analisar a percepção que os falantes do PE teriam das estratégias de tratamento empregadas para estabelecer uma comparação entre PE e PB. A proposta estabelece uma interface entre a perspectiva Sociolinguística laboviana (WEINREICH; LABOV; HERZOG, 2006 [1968]) e a Sociopragmática (BRIZ, 2004) por um viés experimental (KENEDY, 2015). Os resultados do experimento em Lisboa evidenciaram, diferentemente do que fora observado no Rio de Janeiro, um alto grau de aceitabilidade de $t u$ nos diferentes tipos de interação controlados. $O$ mesmo não se verificou para a variante você, que incitou nos participantes um comportamento mais vacilante durante o julgamento, principalmente, quando a forma aparecia como sujeito focalizado. Os resultados mostraram ainda que a forma verbal de $3 \mathrm{SG}$, como sujeito nulo, não seria uma correlata da variante você, pois apresentou aceitação positiva nas relações assimétricas, o que não ocorreu necessariamente com o você explícito.

Palavras-chave: Segunda pessoa; Variação linguística; Sistemas de tratamento; Diferenças entre Português Brasileiro e Português Europeu. 
Abstract: The aim of this paper is to present the results of an experiment carried out in Lisbon to detect the social value assumed by the variants $t u$ and você ('you') in European Portuguese (EP). An experiment of acceptability of the second person forms in subject position was done with 34 Portuguese participants following the model presented by Oliveira, Lopes and Carvalho (2016) with participants from Rio de Janeiro. The objective of the experiment was to analyze the perception that the EP speakers would have of the address forms used in order to establish a comparison between EP and BP (Brazilian Portuguese). The paper proposes an interface between the Sociolinguistic perspective (WEINREICH; LABOV; HERZOG, 2006 [1968]) and the Sociopragmatics (BRIZ, 2004) in an experimental perspective (KENEDY, 2015). The results of the experimental test conducted in Lisbon showed, unlike the ones observed in Rio de Janeiro, a high degree of acceptability of the form $t u$ ('you') in different types of controlled interaction. The same result did not occur for the variant você ('you'), which prompted the participants a more hesitant behavior during the test, especially when the address form appeared as a Focused Subject (Overt Subject). The results also showed that the 3SG verbal form , as null subject, would not be a correlative of the variant você (you), since it presented positive acceptance in the asymmetric relations, which did not necessarily occur with the Overt Subject você ('you').

Keywords: Second person; Linguistic variation; Address systems; Differences between Brazilian Portuguese and European Portuguese.

\section{APRESENTAÇÃO}

Os estudos sobre os sistemas de tratamento pronominal de segunda pessoa (doravante $2 \mathrm{SG}$ ), no português brasileiro (doravante $\mathrm{PB}$ ), demonstraram que a inserção de você, no quadro pronominal, ao lado de tu levou à formação de um paradigma híbrido ou misto, com variações geográficas, sociolinguísticas e pragmáticas (tu e/ou você) (cf. RUMEU, 2008; LOPES; CAVALCANTE, 2011, LOPES et al., 2012; SCHERRE et al, 2015):

\section{Tu-exclusivo}

(1) Achei que tu estava cansado.

(2) Achei que (tu) estavas cansado. 


\section{Você-exclusivo}

(3) Achei que você estava cansado.

Você $\sim t u$

(4) Tu não deve(s) pensar em bobagens, você sabe que eu gosto de você.

Para o português europeu (doravante PE), os trabalhos de Duarte (2011) e Carreira (2004) enfatizam que a complexidade tratamental se dá em outros moldes: uso amplo de tu presente na desinência verbal (2), além do emprego de formas nominais, incluindo prenomes (5-6). No PB, exemplos como (5-6), em que o tratamento é feito com formas nominais em referência ao interlocutor, principalmente prenome, na posição de sujeito, se restringiriam à fala de adultos com crianças na primeira infância. Seu uso entre adultos causaria estranhamento no PB e talvez seja aceito apenas em interrogativas como em (6). Há ainda o uso recorrente no $\mathrm{PE}$ do verbo com desinência formal de $3^{\mathrm{a}}$ pessoa com referência à segunda pessoa do singular sem pronome explícito (8), algo menos comum no $\mathrm{PB}$, em que a presença do pronome é mais frequente (9):
(5) A menina quer sair?
(6) A senhora/o rapaz vai descer no próximo ponto de ônibus?
(7) A Joana está cansada.
(8) Chegou atrasado de novo na escola ${ }^{1}$.
(9) Você quer sair?

Os sistemas de tratamento são bastante diferentes entre si. Enquanto no PB o emprego de vocêé, por sua neutralidade, amplamente aceito e reconhecido pelos seus falantes nas mais diferentes relações interpessoais e regiões, seu uso no PE pode ser considerado inadequado em várias situações interativas e quase inadmissível em outras tantas (cf. DUARTE, 2011, p. 87-88; GUILHERME; BERMEJO, 2015, p. 170).

A complexidade do sistema pronominal de 2 SG do PB se amplia em relação ao PE se forem levados em conta (i) a presença/ausência da desinência verbal canônica de se-

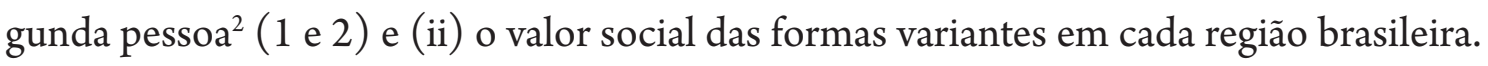

\footnotetext{
${ }^{1}$ Aqui o sujeito seria você no PB ou o prenome no PE.

2 Estamos chamando de canônica a desinência verbal tradicionalmente considerada como de segunda pessoa. Estariam, neste caso, os morfes -ste no \{Pretérito Perfeito do Indicativo\} e o $-s$ nos demais tempos verbais.
} 
Na proposta de Scherre et al. (2015), por exemplo, são identificados em termos diatópicos, pelos menos, seis sistemas de tratamento no português do Brasil falado com base na presença, ou não, da concordância verbal canônica ${ }^{3}$ estabelecida entre o pronome sujeito e o verbo ( $t$ fu falas vs. tu fala_). A questão da concordância afeta obviamente a descrição do fenômeno em função da avaliação social negativa que a ausência da concordância verbal ainda desperta entre os falantes na sociedade brasileira.

Com o intuito de detectar valores positivos ou negativos pelas variantes tu e você no PB, Oliveira, Lopes e Carvalho (2016) realizaram um teste de julgamento de aceitabilidade ou adequabilidade dessas formas em variação na posição de sujeito com falantes do Rio de Janeiro. O intuito era verificar a percepção dos participantes, tendo em vista a influência do tipo de relação interpessoal (simétrica ou assimétrica). O experimento ${ }^{4}$ foi aplicado inicialmente a falantes do Rio de Janeiro pelo fato de ser uma das localidades do Brasil em que as duas formas coexistem no mesmo contexto de uso ${ }^{5}$. As formas variantes em diferentes contextos situacionais foram apresentadas no experimento em legendas inseridas em fragmentos de cenas de filmes e seriados estrangeiros. Os resultados do experimento evidenciaram um alto grau de aceitação de você nos diferentes tipos de interação controlados. $\mathrm{O}$ mesmo não se verificou para a variante $t u$, que incitou nos participantes um comportamento mais vacilante durante o julgamento com maior incidência de nota 3 em uma escala de 1 a 5.

Essa metodologia experimental se mostrou como uma técnica alternativa bastante eficaz para avaliação e percepção dos falantes sobre os usos tratamentais. Os testes experimentais, no modelo testado, parecem ser vantajosos para compreender como determinada comunidade de fala (até aqui a do Rio de Janeiro) julga o uso de tu e você, além de facilitar a identificação mais precisa dos valores sociopragmáticos que podem estar atrelados a essas variantes em cada comunidade analisada com maior distanciamento.

A aplicação desses primeiros testes de percepção/adequação a partir da análise do tratamento em seu contexto de uso (em cenas de vídeo) abre uma perspectiva interessante para os estudos sociolinguísticos por introduzirem uma alternativa metodológica diferente para dar conta do problema da avaliação nos processos de mudança (WEINREICH;

\footnotetext{
${ }^{3}$ Para facilitar a descrição comparativa entre PE e PB e pela falta de terminologia adequada, estamos nos referindo à presença de concordância verbal entre o pronome tu e o verbo quando as marcas desinenciais de segunda pessoa estão presentes. A ausência das desinências canônicas, mencionadas na nota anterior, está sendo considerada como ausência de concordância verbal. Neste último caso, podemos também usar a denominação de verbo na $3^{\text {a }}$ pessoa ( $3 S G$ ) apenas para facilitar e uniformizar terminologicamente o texto.

${ }^{4} \mathrm{O}$ experimento foi preparado sob a supervisão do Professor Doutor Eduardo Kenedy da UFF a quem muito agradecemos pela orientação preciosa e imprescindível.

5 A ideia obviamente é realizar o mesmo experimento em outras localidades.
} 
LABOV; HERZOG, 2006 [1968]). Obviamente que o refinamento da técnica e a sua aplicação a diferentes comunidades de fala contribuirão para uma descrição mais apurado do fenômeno. Trata-se ainda de um experimento piloto.

Tendo como base o experimento feito no Brasil para a análise da percepção/adequação das formas, resolveu-se aplicar a portugueses de Lisboa o mesmo teste feito com brasileiros (por enquanto do Rio de Janeiro), fazendo, obviamente, os ajustes linguísticos necessários para que as escolhas lexicais e certas estruturas linguísticas não se sobreponham ao fenômeno em foco da pesquisa: formas de tratamento verbo-pronominais.

O objetivo do experimento piloto é analisar a percepção que os falantes do PE têm das estratégias de tratamento empregadas para estabelecer uma comparação entre PE e PB. A proposta procura assim estabelecer uma interface entre a perspectiva Sociolinguística laboviana (WEINREICH, LABOV e HERZOG, 1968 [2006]) e Sociopragmática (BROWN; GILMAN, 1960; BRIZ, 2004, etc) por um viés experimental (cf. DERWING; DE ALMEIDA, 2005; SCHÜTZE; SPROUSE, 2013; KENEDY, 2015). As hipóteses testadas nos experimentos de percepção e avaliação foram levantadas a partir dos resultados obtidos em alguns dos estudos que descrevem os usos linguísticos das formas de tratamento feitos até o momento no Brasil (cf. RUMEU, 2008; MACHADO, 2006; LOPES et al, 2009, SCHERRE et al, 2015, etc).

O artigo está organizado em quatro partes além desta introdução e das considerações finais. No item 2, é descrito o objeto de estudo com base nos estudos de autores brasileiros e portugueses sobre os sistemas de tratamento de segunda pessoa nos dois territórios. Nas seções 3 e 4 são apresentados os pressupostos teóricos e a metodologia empregada para a realização do experimento em Lisboa. Na seção 5, apresentam-se os resultados gerais quantificados, contrastando, em um primeiro momento, com os resultados obtidos no teste realizado no Rio de Janeiro. Nesta seção são apresentadas ainda algumas observações relativas à atuação do fator etário dos participantes portugueses, concluindo a seção com a análise dos padrões estruturais testados. Em 6 e 7, são feitas as considerações finais e a indicação das referências bibliográficas utilizadas. Segue, por fim, um anexo com as frases experimentais utilizadas no experimento. 


\section{DESCRIÇÃO DO OBJETO DE ESTUDO: OS SISTEMAS DE TRATAMENTO NO BRASIL E EM PORTUGAL}

\subsection{Panorama geral dos estudos sobre o tratamento no Brasil e as análises empíricas} do subsistema você/ $\mathbf{t} u$ no Rio de Janeiro

A forte tradição de trabalhos sob a perspectiva da Sociolinguística Quantitativa no Brasil já nos permitiu delinear, com base em dados de fala, alguns dos subsistemas de tratamento em vigor nas principais regiões brasileiras. $\mathrm{O}$ vasto levantamento feito por Scherre et al. (2015) dos estudos realizados por pesquisadores brasileiros, como mencionado, levou os autores a proporem a seis subsistemas, tendo em vista a presença ou não de concordância verbal, ilustrados na figura 01 .

Figura 1. Mapeamento da variação você/tu no $\mathrm{PB}$
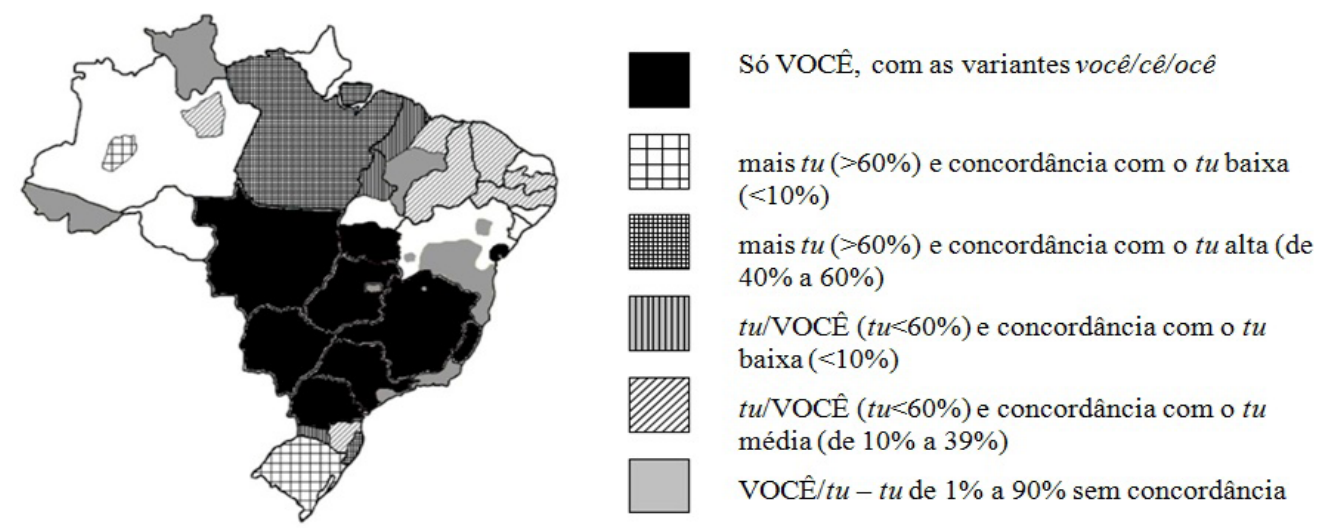

VOCÊ $/ t u-t u$ de $1 \%$ a $90 \%$ sem concordância

Fonte: Scherre et al. (2015, p. 142).

Com relação aos resultados relativos ao Rio de Janeiro (localidade onde foi realizado o primeiro experimento piloto proposto), alguns estudos empíricos sobre o comportamento variável de você e $t u$ com dados de fala apontam para um uso menos frequente do pronome $t u$ (sem a desinência verbal canônica de $2 \mathrm{SG}$ ) em relação ao emprego de você (cf. PAREDES SILVA, 1996, 2003; LOPES et al., 2009; SANTOS, 2012; LOPES; SANTOS, 2012). Os trabalhos de Paredes Silva (1996 e 2003) feitos com base em entrevistas sociolinguísticas dos anos de 1980 e 2000 e com gravações não ocultas (1989-90) mostram que os percentuais de $t u$ não ultrapassaram $7 \%$ no falar carioca. $O$ estudo de Santos $(2012$, p. 63-70, 91, 109) obteve $12 \%$ de frequência de uso para $t u(12 \%)$ nas gravações ocultas de conversas estimuladas em diversos bairros do Rio de Janeiro.

O estudo de Santos (2012) é bastante representativo pelo fato de a autora ter leva- 
do em conta perfis profissionais diferentes (ambulantes, vendedores, gerentes de banco e advogados) e regiões também distintas do Rio de Janeiro (RJ): centro da cidade, Tijuca (bairro conservador na zona norte) e Campo Grande (antiga região rural e distante do centro da cidade). As amostras foram organizadas seguindo uma metodologia similar a usada por Labov (1966): o entrevistador aborda um informante nas ruas ou em uma loja e pede orientação de como chegar a um determinado lugar ou como obter algum serviço. Trata-se de uma amostra constituída por sequências injuntivas, pois o entrevistado ensina o entrevistador a executar uma determinada tarefa. As questões gatilhos foram assim formuladas: Como eu chego à rua X? Como eu posso revelar foto de câmera digital? As respostas normalmente são iniciadas por uma das variantes: "Tu/você vai por essa rua”.

Santos (2012) obteve 648 ocorrências de formas de referência à 2SG na posição sujeito, sendo 318 de você (49\%), 251 de verbo na 3SG (39\%) e 79 dados de tu (12\%). Em termos da distribuição geográfica, o pronome tu mostrou-se favorecido na região oeste (antiga área rural) da cidade do Rio de Janeiro e entre trabalhadores ambulantes no centro da cidade (em torno de 20\%). Cabe lembrar que a forma tu ocorre no RJ sempre sem a concordância canônica ( $t u$ fala no lugar de tu falas), por isso seria considerada estigmatizada socialmente. Com relação ao nível de escolaridade, os resultados demonstraram que mesmo os informantes com mais de 12 anos de escolaridade e com nível superior completo apresentaram produtividade para tu semelhante à observada entre os falantes nos demais níveis de escolaridade (em torno de 10\%). Esses resultados suscitaram a necessidade de discutir sobre os possíveis valores sociais assumidos por você e tu na fala do Rio de Janeiro, o que nos incitou a realizar os testes de avaliação de uso pelo viés experimental.

\subsection{Breve descrição do tratamento em Portugal: estudos diversos}

Para o português europeu, os estudos disponíveis não são, em geral, de natureza empírica nos moldes da Sociolinguística laboviana, mas calcados em: a) questionários que indagam sobre as formas de tratamento usadas para $\mathrm{X}$ ou $\mathrm{Y}$; b) dados históricos, literários, dialetológicos; e c) perspectivas teóricas de cunho interacional (cf. CINTRA, 1972; GYULAI, 2011; GUILHERME; BERMEJO, 2015; MEDEIROS, 1985; HAMMERMÜLLER, 1993, LEŠKOVÁ, 2012; CARREIRA, 1997, 2001, 2002, 2004 , etc). Os trabalhos centram-se bastante na proposição de critérios para distinguir a constituição do sistema de tratamento do português europeu, tendo em vista uma distribuição tríade ${ }^{6}$ entre formas pronominais ( $t u$, você, vocês), nominais (o senhor, o doutor, o

${ }^{6}$ Ver Cintra (1972, p. 12-13). 
professor, o senhor Ministro) e verbais (__ Desejas ___ Deseja alguma coisa?). Critérios interacionais também são observados, opondo formas alocutivas ( tu, você, o(a) senhor (a), o(a) doutor(a), o João etc.) e delocutivas (ele(s), ela(s), o(a) senhor(a) professor(a), etc.). ${ }^{7}$

No que se refere às formas verbo-pronominais, os estudos costumam reiterar a posição de Cintra (1972) quando afirmam que você no PE seria empregado entre iguais que não tenham, entretanto, intimidade. Seu emprego também seria usual, em alguns casos, nas relações de inferior a superior (filhos para pais). Entretanto, Guilherme e Bermejo (2015) afirmam que, nesses dois contextos tradicionalmente apontados, o emprego de você seria marcado como pejorativo ou indelicado (FARIA, 2009; CARREIRA, 2002). Na verdade, a suposta aceitação atribuída a você refere-se, segundo os autores, ao emprego de formas verbais de 3a pessoa e não ao emprego explícito de você como sujeito pleno. Por razões diferentes, você no PE poderia ser considerado, como ocorre em geral no PB, como um tratamento polifuncional, por conta desses seus diferentes valores mencionados desde Cintra (1972). No PE, segundo Guilhermo e Bermejo (2015), o uso de você é marcado pela neutralidade e caráter heterogêneo pelos seus vários contextos de uso (relações de poder assimétricas, intimidade entre classes mais abastadas e entre iguais com deferência). No PB, entretanto, a neutralidade de você assume outro caráter na maior parte das localidades. Diferentemente dos valores mencionados para o PE, a forma você no Brasil seria uma estratégia não-marcada que pode funcionar, ao mesmo tempo, como variante do íntimo tu, além de poder ser empregada em relações assimétricas, principalmente, entre conhecidos da mesma faixa etária. Trata-se de um uso bem generalizado que só é, eventualmente, substituído por o senhor/a senhora com pessoas bem mais velhas e nas relações transacionais entre completos desconhecidos para marcar distanciamento. Com base nessas distinções, a proposta do experimento no PE parece adequada, principalmente, para testar a natureza desse suposto valor neutro de você. Como Guilhermo e Bermejo (2015) afirmam:

este valor neutro do pronome (você) parece não ser assim tão claramente entendido e julgado por muitos falantes. Isto é, tal neutralidade é até certo ponto questionável por muitos, na medida em que, no momento da seleção da forma de tratamento, é comum optarem-se por outras estratégias, nomeadamente, formas verbais de $3 \mathrm{sg}$ (sujeito nulo) ou grupos nominais. (GUILHERMO; BERMEJO, 2015, p. 170, grifo nosso).

O estudo realizado por Lešková (2012, p. 55) com base na aplicação de um ques-

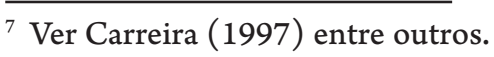


tionário a 88 falantes do português europeu também mostrou resultado semelhante. $\mathrm{O}$ julgamento das formas de tratamento aplicado pela autora levava em conta a oposição entre proximidade e distanciamento. Os resultados quantitativos confirmam, no geral, o que outros autores já destacaram: a forma você foi a estratégia menos produtiva em praticamente todas as situações intuitivas propostas. Numa sequência de perguntas, a autora apresentava as seguintes formas na posição de sujeito (a senhora/o senhor, a senhora/o senhor + prenome, prenome, verbo na 3 a pessoa do singular, você, verbo na $2 a$ pessoa do singular), formulando uma pergunta sobre horas: A senhora/a senhora Maria/ A Maria/VP3/ você tem/tens horas? Nos resultados globais, Lešková mostra que homens, em relações familiares ou entre amigos, optaram majoritariamente pela forma verbal associada a $t u$ (Tens horas?) com $78 \%$ de frequência. Para pessoas de idade inferior, as formas na $3^{\text {a }}$ pessoa (3SG) (Tem horas?) e na $2^{\text {a }}$ pessoa (2SG) (Tens horas?) foram frequentes entre mulheres e homens. Enquanto estes mantiveram o tratamento $t u^{8}(43 \%)$, aquelas optaram pelo verbo na $3^{a}$ pessoa $(35 \%)$. Para pessoas de idade superior ou para desconhecidos, homens e mulheres escolheram preferencialmente o tratamento de base nominal (o senhor/a senhora). Cabe destacar ainda que, quando questionados sobre o fato de se sentirem ofendidos por serem tratados por você, 36,6\% responderam que SIM e 63,64\% responderam NÃO. A rejeição por você fica mais nítida com os resultados relativos à questão: quando usa você? A resposta mais frequente foi "não uso" com 53\%. Na mesma linha interpretativa levantada por Guilhermo e Bermejo (2015), o trabalho anterior de Lešková (2012, p. 62) já demonstrava que os portugueses têm um julgamento negativo para a forma você, porque o seu contexto de uso aparentemente não é bem delimitado.

Por fim, o estudo de Nascimento, Mendes e Duarte (2018) comenta que o sistema de tratamento do PE está sofrendo alterações nos últimos 30 anos, talvez por influência da televisão brasileira. As autoras ainda defendem que os jovens estariam usando a forma você nas relações assimétricas.

Com base, principalmente, nos resultados quantitativos de Lešková (2012) e nas observações de Guilhermo e Bermejo (2015) e Nascimento, Mendes e Duarte (2018), algumas hipóteses foram formuladas para os primeiros testes realizados com falantes nativos do português europeu, em particular de Lisboa:

a) existe uma diferença na avaliação das formas de tratamento verbo-pronominais: verbo na segunda pessoa (2SG), verbo na terceira pessoa (3SG) e você (sujeito pleno)

\footnotetext{
${ }^{8}$ É preciso destacar que, diferentemente do que ocorre no Brasil, o pronome tu aparece explícito e o verbo, na maioria das vezes, está na sem a marca desinencial canônica de segunda pessoa, o teste aplicado a falantes do português europeu apresentava a forma verbal com desinência de segunda pessoa com ausência do pronome sujeito.
} 
no português europeu. Tal diferença sofre influência do tipo de relação interpessoal e/ou pela proximidade ou distanciamento estabelecida entre os interlocutores; b) a forma você, diferentemente do que ocorre, em geral, no Brasil, teria um julgamento negativo nas diferentes relações interpessoais (simétricas, assimétricas);

c) a forma verbal de $3 \mathrm{SG}$, e não a variante você, teria julgamento mais positivo pelos falantes portugueses, nas mais diferentes relações interpessoais, ao passo que a variante $t u$ (ou seja, a forma verbal na $2 \mathrm{G}$ ) seria bem avaliada nas relações interpessoais de maior proximidade entre os interlocutores.

\section{PRESSUPOSTOS TEÓRICO-METODOLÓGICOS}

A preocupação com a percepção dos falantes em relação aos fenômenos linguísticos variáveis não é recente nos estudos sociolinguísticos. No ensaio de 1968, Weinreich, Labov e Herzog referem-se a essa questão como o Problema da Avaliação e o consideram uma importante propriedade para a análise dos processos de mudança linguística. Os autores defendem a importância de identificar correlatos subjetivos das mudanças objetivas observadas direta ou indiretamente. No primeiro caso, se medem as reações dos informantes a partir do valor do fenômeno variável, no segundo, se correlaciona a atitude do informante quanto ao seu comportamento linguístico.

A percepção estaria mais relacionada à análise indireta do problema da avaliação, pois, como afirma Oushiro $(2015$, p. 32), a percepção se relaciona às inferências conscientes e inconscientes feitas pelos usuários ao ouvir outro falante.

Diferentemente dos estudos que aplicam questionários para avaliar a forma de tratamento mais ou menos adequada a uma pessoa com certo perfil social - um idoso, um profissional etc (cf. BALSALOBRE, 2015), a nossa proposta de análise experimental visa a compreender como em duas comunidades de fala distintas (uma no Brasil e outra em Portugal) os falantes julgam o uso de $t u$, você e outras formas de referência à $2^{\text {a }}$ pessoa (prenome, verbo na 3SG, etc), tendo em vista os valores sociopragmáticos que podem estar atrelados a essas variantes. A nossa restrição aos questionários está no fato de nem sempre as respostas do informante corresponderem ao que ele efetivamente produz (ou acha que produz), pois suas possíveis respostas se baseiam meramente em convenções sociais. Por essa razão, consideramos que métodos alternativos, como o experimento proposto neste estudo, podem ser vantajosos, uma vez que o participante não sabe de antemão que o seu julgamento das cenas assistidas será da forma de tratamento empregada, mas se a legendagem é adequada à situação interativa mostrada nas cenas vistas. 
Para a organização das cenas, são apresentados fragmentos de episódios de filmes e seriados, nos quais havia diversos tipos de relações sociais entre os personagens. Os tipos de relação controlados basearam-se nos fundamentos básicos propostos Brown e Gilman (2003 [1960]). Bastante recorrente para a análise do tratamento, os autores postulam que as relações sociais são governadas por um sistema bidimensional que marca Poder (P) e Solidariedade (S). O Poder representaria as relações verticais, diferenciáveis ou não recíprocas (diferentes faixas etárias, gêneros ou posições hierárquicas institucionais). As relações estariam governadas por algum tipo de hierarquia estabelecida em distintos níveis: pai-filho, professor-aluno, patrão-empregado etc. Se, ao contrário, existir uma relação horizontal ou recíproca, teríamos o eixo da Solidariedade. Os estudos que trabalham à luz desses pressupostos discutem ainda que as sociedades contemporâneas estariam se tornando mais abertas e igualitárias, substituindo o eixo do Poder pelo da Solidariedade. Nesse sentido, haveria a diminuição da frequência de tratamento verticalizado e hierárquico em favor de um tratamento horizontal e recíproco, talvez mais no Brasil que em Portugal, representados, por enquanto, pelo Rio de Janeiro e por Lisboa.

Briz (2004, p. 80) apresenta tais conceitos com base em outras noções. O autor considera que a Solidariedade se refere a relações de proximidade e simetria entre os interlocutores, que são negociadas e construídas na interação, independentemente do estatuto social previamente definido. São relações mais simétricas ou de proximidade aquelas em que existe, ou se percebe, igualdade funcional entre os participantes da interação, no que diz respeito ao papel assumido, à idade, gênero ou profissão. Fatores sociopragmáticos são responsáveis pelas interações de maior proximidade, como o fato de os interlocutores terem mais experiências ou saberes compartilhados, maior grau de contato (físico ou ocular) e de compromisso afetivo. Esses elementos se encontram preferencialmente reunidos no caso das relações ditas interpessoais. As relações ditas transacionais, por sua vez, seriam assimétricas por definição, pois o papel funcional, os direitos e as obrigações se apresentam de algum modo determinados e mais estritamente submetidos a convenções sociais.

\section{METODOLOGIA EMPREGADA}

Para analisar a percepção dos participantes acerca dos pronomes tu e você, a partir do julgamento de seu uso em legendas de cenas de vídeos, foi proposto um experimento específico ao fenômeno em questão que foge um pouco dos modelos convencio- 
nais da Linguística Experimental (cf. DERWING; DE ALMEIDA, 2005; SCHÜTZE; SPROUSE, 2013; KENEDY, 2015). A técnica consiste em apresentar aos participantes enunciados que contenham o fenômeno linguístico em estudo e pedir a eles que respondam, através de uma escala de notas, o quão aceitáveis ou naturais são os enunciados em relação aos contextos de uso (cenas com relações simétricas e assimétricas). Trata-se de um teste off-line controlado ${ }^{9}$ e mascarado, sem ser explicitamente metalinguístico, uma vez que o participante analisa o fenômeno indiretamente julgando apenas a adequação das legendas assistidas por ele. Outro aspecto interessante do experimento é a presença de enunciados (legendas) contextualizados nas cenas recortadas de filmes/séries, o que é fundamental para o estudo do tratamento. Isso se deve ao fato de as escolhas tratamentais serem sensíveis ao perfil da relação entre interlocutores específicos, que interagem em uma situação comunicativa também específica (no caso, são os personagens que aparecem na cena).

Essa opção metodológica nos traz algumas vantagens. Primeiramente, a apresentação das variantes em forma de legenda resolve o problema da natureza dialógica do fenômeno variável em análise, visto que tu e você são formas linguísticas típicas das sequências textuais de diálogo, que seriam mais difíceis de construir sem o auxílio do vídeo. Além disso, nosso experimento, da maneira como foi elaborado, goza de maior validade ecológica, uma vez que o participante desempenha uma tarefa comum e familiar na sua vida cotidiana, que é assistir a cenas legendadas em vídeos curtos ${ }^{10}$, como ocorre em filmes/ séries televisivas.

Outra decisão metodológica importante diz respeito às situações interativas nas quais apareceriam os pronomes de 2SG. Para a seleção das cenas utilizadas, são levados em conta vários contextos situacionais de maior/menor formalidade e a presença de personagens que possuíssem maior/menor intimidade entre si.

O Quadro 1 elenca as situações e os tipos de interlocutores selecionados para o experimento. Na primeira linha, indicam-se os pronomes que foram inseridos nas legendas do experimento. Na segunda linha, constam as relações previstas e nas respectivas colunas o contexto da cena:

\footnotetext{
9 Trata-se de um método não-cronométrico, porque não se mede o tempo de reação ou resposta do participante (ver detalhes em Maia e Finger, 2005, p. 401).

${ }^{10}$ Os participantes eram informados que não se tratava do diálogo original do filme ou da série. Eles sabiam que eram legendas inseridas em vídeos que foram criadas para o experimento.
} 
Quadro 01. Situações comunicativas e tipos de interlocutores selecionados para o experimento

\begin{tabular}{llll}
\hline \multicolumn{2}{c}{ VOCÊ } & \multicolumn{2}{l}{ TU } \\
\hline Relações simétricas & Relações assimétricas & Relações simétricas & Relações assimétricas \\
\hline $\begin{array}{l}\text { (1) Grupo de amigos } \\
\text { conversando em um bar }\end{array}$ & $\begin{array}{l}\text { (1) Advogada e prisio- } \\
\text { neiro (cliente) }\end{array}$ & $\begin{array}{l}\text { (1) Casal discutindo em } \\
\text { apartamento }\end{array}$ & $\begin{array}{l}\text { (1) Aeromoça e passa- } \\
\text { geiro no avião }\end{array}$ \\
\hline $\begin{array}{l}\text { (2) Casal discutindo a } \\
\text { relação na rua }\end{array}$ & $\begin{array}{l}\text { (2) Médico e paciente } \\
\text { no hospital }\end{array}$ & $\begin{array}{l}\text { (2) Dois presidiários na } \\
\text { cadeia }\end{array}$ & $\begin{array}{l}\text { (2) Rapaz e menino em } \\
\text { casa }\end{array}$ \\
\hline $\begin{array}{l}\text { (3) Casal de namorados } \\
\text { jovens conversando }\end{array}$ & $\begin{array}{l}\text { (3) Advogado e presidiá- } \\
\text { rio na cadeia }\end{array}$ & $\begin{array}{l}\text { (3) Casal de namorados } \\
\text { jovens na praia }\end{array}$ & (3) Reunião de negócios \\
\hline $\begin{array}{l}\text { (4) Diálogo entre mari- } \\
\text { do e mulher no altar do } \\
\text { casamento }\end{array}$ & $\begin{array}{l}\text { (4) Cliente e funcionária } \\
\text { numa lanchonete }\end{array}$ & $\begin{array}{l}\text { (4) Diálogo entre } \\
\text { amigos de trabalho no } \\
\text { escritório }\end{array}$ & $\begin{array}{l}\text { (4) Cliente e funcionária } \\
\text { no caixa do supermer- } \\
\text { cado }\end{array}$ \\
\hline $\begin{array}{l}\text { (5) Dois amigos conver- } \\
\text { sando no trem }\end{array}$ & $\begin{array}{l}\text { (5) Advogada e Juíza no no } \\
\text { tribunal }\end{array}$ & $\begin{array}{l}\text { (5) Duas amigas em um } \\
\text { bar }\end{array}$ & $\begin{array}{l}\text { (5) Policial e motorista } \\
\text { em Blitz }\end{array}$ \\
\hline
\end{tabular}

Fonte: Elaborado pelas autoras.

\subsection{Etapas de elaboração do experimento e previsões iniciais}

A primeira etapa da elaboração do experimento consistiu em assistir diversos vídeos de filmes e seriados on-line no site do YouTube para selecionar as cenas que poderiam atender aos requisitos de simetria/assimetria e/ou proximidade/distância entre os personagens e de (in)formalidade da situação. Para o experimento-piloto realizado no Brasil (Rio de Janeiro), foram controladas as seguintes variáveis independentes: o pronome de 2SG em si ( $t u$ ou você) e o tipo de relação social (simétrica e assimétrica).

A etapa seguinte à seleção dos vídeos prevê os recortes e edição de cenas no computador. Na edição, o som do original é apagado, visto que mantê-lo poderia desconcentrar os participantes durante o experimento. Cada cena é preparada com um tempo de duração aproximado de 15 segundos para não gerar um desgaste excessivo nos participantes, o que pode comprometer os resultados.

A terceira etapa consiste na elaboração das legendas adicionadas aos fragmentos de cena. Para o experimento aplicado em Lisboa, foram feitas adaptações linguísticas sob a supervisão de um nativo do português europeu para que o estranhamento vocabular, contextual e cultural não interferisse na análise do objeto de estudo. Foram 30 cenas selecionadas para o primeiro modelo de experimento aplicado em Lisboa, 20 delas continham um pronome de $2 \mathrm{SG}$ (10 cenas com tu e 10 cenas com você). As formas de tratamento apareciam sempre na última legenda de cada cena (exibida na cor vermelha). As outras 10 eram cenas distratoras, inseridas com o intuito de despistar os participantes quanto ao fenômeno investigado. A diferença, no entanto, entre as cenas experimentais e 
as distratoras é que nestas últimas não havia pronome de 2SG (embora, como nas outras, a última legenda também aparecesse sinalizada na cor vermelha).

Após a fase de edição e legendagem descritas, as cenas são reunidas e programadas no Psyscope (COHEN; MACWHINNEY; PROVOST, 1993) ${ }^{11}$, software gratuito bastante utilizado em experimentos psicolinguísticos. Através desse programa, as cenas podem ser aleatorizadas, isto é, programadas de maneira que cada participante possa assistir às 30 cenas em ordens diferentes.

A aplicação do teste aos participantes tem duas fases e leva, em média, 12 minutos para a sua realização completa. A primeira fase consiste em um treinamento. Os participantes recebem as instruções para a realização do experimento e avaliam 4 cenas extras. Os indivíduos são instruídos a assistir atentamente aos fragmentos, uma vez que não seria possível paralisar a exibição do vídeo ou rever a mesma cena. Na segunda fase, o teste é iniciado. As cenas trazem cinco legendas apresentadas na cor branca, com a finalidade de criar um pequeno diálogo para a situação representada no vídeo assistido ${ }^{12}$. A cena final apresenta uma legenda na cor vermelha. Ao final de cada vídeo ${ }^{13}$, o participante tem que avaliar a qualidade do texto da legenda de cor vermelha, atribuindo notas de 1 a 5. A orientação dada aos participantes era a de que as notas seriam dadas em função de eles considerarem os usos linguísticos da legenda possíveis e/ou comuns em sua variedade ou dialeto. Essa avaliação é medida através da escala numérica de 5 pontos (escala Likert). Os participantes são orientados, assim, a atribuir Nota 1 (a mais baixa) para as legendas consideradas muito ruins ou inadequadas em relação à cena assistida no vídeo. A Nota 5 (a mais alta) é atribuída às legendas consideradas muito boas ou adequadas em relação à cena. As Notas 2, 3 e 4 são intervalares entre os extremos da escala. As notas são acionadas no teclado numérico do MacBook Pro, através do qual os participantes também controlam o início de cada nova cena, clicando na barra de espaços. Além de registrar automaticamente as notas atribuídas pelos participantes, o Psyscope (COHEN; MACWHINNEY; PROVOST, 1993) marca também o tempo que cada um deles levou para emitir sua nota, mas esse aspecto não foi usado por ora em nosso estudo.

Foi feito ainda um controle do perfil dos participantes (fatores extralinguísticos como o gênero, faixa etária e localidade de nascimento) a partir de uma ficha de identificação preenchida pelos participantes ao final do teste.

\footnotetext{
${ }^{11}$ Agradecemos ao Professor Doutor Eduardo Kenedy, da Universidade Federal Fluminense, pelo precioso auxílio nesta etapa de programação do experimento.

${ }^{12}$ Em anexo, apresentamos o texto completo das cenas com as frases experimentais.

13 A figura 2, em 5.2, apresenta o print completo de um dos diálogos usados no experimento para que se tenha ideia de como o experimento foi feito.
} 
No teste realizado em Lisboa, tivemos quatro condições experimentais: tu-simétrico, tu-assimétrico, você-simétrico, você-assimétrico. Para cada condição foram propostos cinco padrões frasais distintos: (1) construções de tópico-comentário: Você, inocente? Todos os presos dizem o mesmo; (2) construções de elipse, sejam coordenadas sejam estruturas comparativas; Sou tão culpado do crime quanto você (é); (3) construção em que o pronome aparece dentro do sintagma nominal, com adjunto: $E$ [os rapazes, inclusive você,] SUJ levaram com a culpa; (4) construções com sujeito pleno focalizado: Foi você mesmo que nos disse; (5) construções com sujeito nulo:... é impossível, só pode estar louca!

A previsão inicial era a de que os portugueses de Lisboa apresentariam um resultado bastante diferente do que fora observado no teste aplicado no Rio de Janeiro (Brasil): alto grau de aceitabilidade do uso de $t u$ (como sujeito nulo) na maior parte das interações propostas e avaliação negativa quanto ao emprego de você: notas altas (entre 4 e 5 ) para tu e notas baixas para você (entre 1 e 2 ).

\subsection{Participantes}

O experimento foi aplicado a 35 indivíduos portugueses, mas um teste teve que ser descartado, porque o participante deu notas máximas para todos os itens experimentais, inclusive para os distratores ruins. Assim, contabilizamos 34 julgamentos, aplicados a 15 de estudantes, 14 de investigadores e 05 de professores da Universidade de Lisboa e da Universidade Nova. Além da diferença em termos de categoria profissional, controlamos também outras variáveis grupais: o nível de escolaridade dos participantes, o gênero, a faixa etária e o local de nascimento. Participaram do teste 09 Doutores, 10 Mestres e 15 Licencia(n)dos. Em termos da distribuição por faixa etária e gênero, temos mais informações no quadro 2.

Quadro 02. Número de participantes que realizaram o experimento: outras variáveis grupais controladas

\begin{tabular}{|c|c|c|c|c|}
\hline \multirow{2}{*}{$\begin{array}{c}\text { Faixa } \\
\text { etária }\end{array}$} & Idades & \multicolumn{2}{|c|}{$\mathrm{N}^{\mathrm{o}}$ participantes } & \multirow{2}{*}{ Total } \\
\cline { 3 - 4 } & & Fem. & Masc. & \\
\hline 1 & 15 a 24 anos & 10 & 4 & 14 \\
\hline 2 & 25 a 34 anos & 6 & 2 & 8 \\
\hline 3 & 35 a 44 anos & 4 & 2 & 6 \\
\hline 4 & Acima de 45 anos & 5 & 1 & 6 \\
\hline & Total & 25 & 9 & 34 \\
\hline
\end{tabular}

Fonte: Elaborado pelas autoras. 
Todos os participantes vivem em Lisboa, mas são nascidos em localidades distintas, o que dá certa representatividade ao teste. Da área Setentrional tivemos cinco participantes: Chaves (1), Guarda (1), Seia (1), Porto (1) e Coimbra (2). Indo em direção ao centro-meridional, tivemos: Nazaré (1) e Ericeira (1). Oriundos de Lisboa foram 14 participantes, além de 02 de Torres Vedras. Mais do centro interior e do Sul, foram: Setúbal (1), Porto Alegre (1), Campo Maior (1), Évora (1), Beja (2), Faro (Portimão) (1). Ainda houve um participante de origem açoriana e dois oriundos de Angola. O mapa 1 ilustra a diversidade de origem dos participantes.

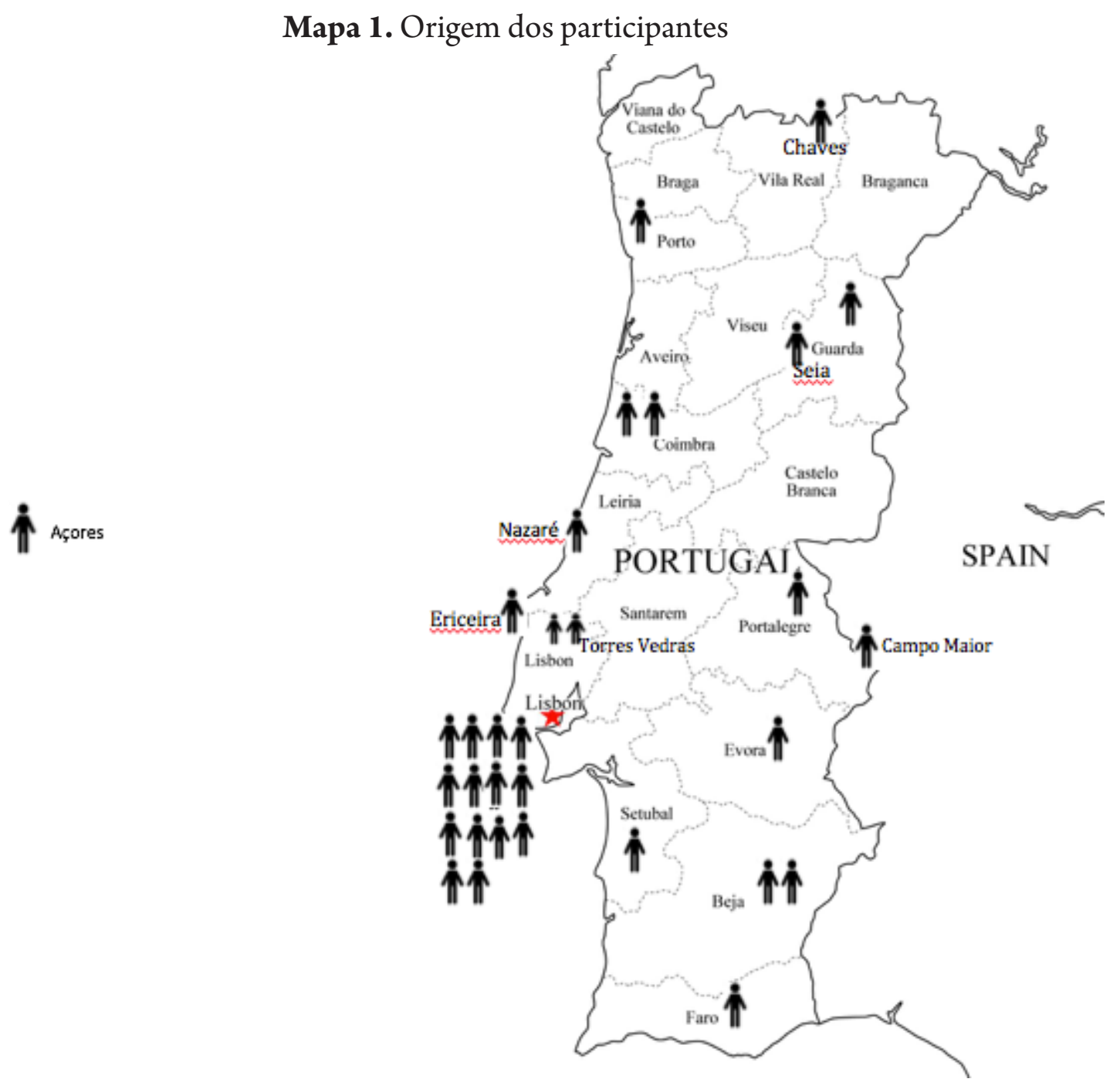

Fonte: Elaborado pelas autoras. 


\section{RESULTADOS E DISCUSSÃO}

Os dados foram organizados em uma planilha do Excel com as notas dos julgamentos dos participantes, as frases experimentais e outras informações do teste. Além de tabelas dinâmicas fornecidas pelo Excel, realizamos, a partir do Programa R, testes de significância estatística como o WILCOXON: método não paramétrico de comparação de médias e variância de duas amostras pareadas para confronto das diferenças das notas. O teste indica a significância das diferenças comportamentais apresentadas com base no $p$-valor. São consideradas estatisticamente significativas aquelas em que o $p$-valor é menor que $0,05(p<0,05)$ e não significativas quando o $p$-valor é maior do que $0,05(p>0,05)$. A significância indica se a diferença observada é ou não aleatória, isto é, se aconteceu ou não ao acaso. Serão apresentadas as variáveis estatisticamente relevantes (relação social e tipo de frase). Teceremos comentários sobre a faixa etária, embora essa última não tenha apresentado relevância estatística.

No total foram obtidos 680 julgamentos a partir das notas atribuídas pelos 34 participantes às 20 legendas do experimento: 340 avaliações para tu e 340 para você.

Como mencionado, a hipótese era a de que o tipo de relação (simétrica ou assimétrica) detectada na cena influenciaria no julgamento das legendas feito pelos participantes. Para o PE, representado por participantes de Lisboa, o pronome $t u$ teria julgamento mais positivo ${ }^{14}$ nas cenas com dois tipos de relação, preferencialmente nos contextos de simetria entre os personagens envolvidos nas cenas vistas. A forma você teria julgamento mais negativo, ou seja, as notas seriam menores que 3 (cf. GUILHERMO; BERMEJO, 2015, entre outros).

Os resultados gerais estão no gráfico de caixas 01 (boxplot) que apresenta a concentração das notas atribuídas pelos participantes à forma tu ou você em função do tipo de relação. Os boxes representam a concentração das notas a partir da escala de 1 a 5 . As linhas em negrito (mais densas) correspondem às medianas e indicam a tendência central das notas atribuídas ${ }^{15}$. Os tracejados, por seu turno, sinalizam apenas a dispersão das notas pela escala. Assim, pela ordem, o primeiro box representa a concentração das notas do pronome tu em legendas com cenas de relações assimétricas (= tuass), o segundo, as notas de tu-simétrico $($ tusim $)$ e assim por diante $($ você-assimétrico $=v c a s s$ e você-simétrico $=v c s i m)$ :

\footnotetext{
${ }^{14}$ Estamos chamando de positivo e negativo tendo em vista a escala Likert.

${ }^{15} \mathrm{Na}$ escala proposta de 1 a 5 , se a mediana for 4 ou 5, isso significa que a condição teve uma avaliação positiva, ao passo que se a mediana for 1 ou 2, a condição em análise teve avaliação negativa. Medianas próximas de 3 sinalizam que o julgamento ficou em um ponto neutro.
} 
Gráfico 1: Julgamento dos participantes de Lisboa

para as formas de $2 \mathrm{SG}$ em função do tipo de relação:

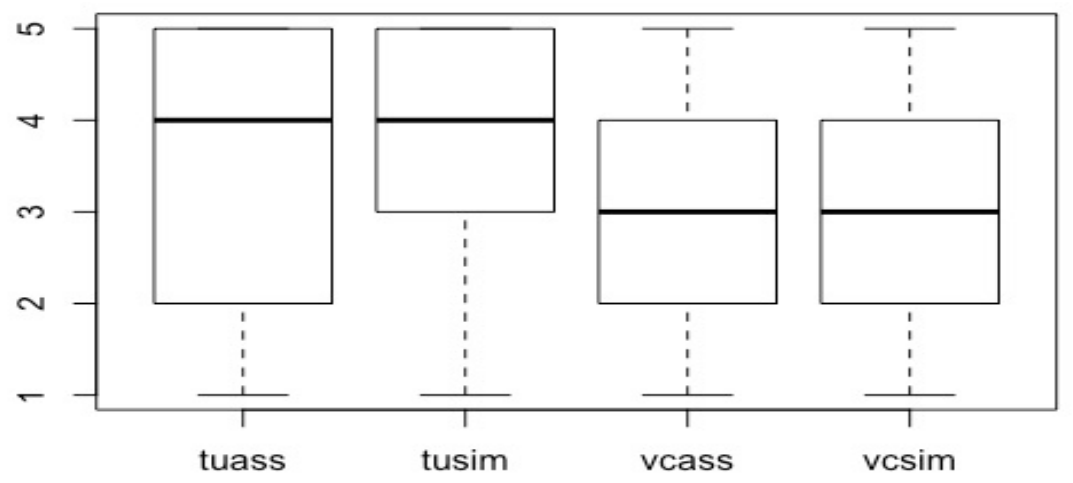

Fonte: Elaborado pelas autoras.

O gráfico 1 confirmou nossa hipótese sobre o PE sobre a avaliação mais positiva para $t u$ em relação ao pronome você. As legendas com o pronome $t u$ foram as mais bem julgadas no experimento com mediana 4 nas cenas dos dois tipos de relação. Percebe-se, porém, que as caixas (boxes) para a avaliação da forma tu são diferentes: para tu-simétrico as notas se concentram entre 3 e 5, para tu-assimétrico, por sua vez, as notas estão distribuídas entre 2 e 5 . Isso significa que o pronome $t u$ foi mais bem avaliado nas cenas de relações simétricas do que nas assimétricas. Nessas últimas, recebeu um julgamento mais disperso em termos da escala de notas. Os julgamentos do pronome você, por outro lado, considerando os dois tipos de relação, são bastante equivalentes e se concentram entre os pontos 2 e 4 da escala com mediana 3 (julgamento mais neutro) nos dois tipos de relação.

Em termos de relevância estatística, o teste $W_{i l c o x o n}{ }^{16}$ demonstrou que o resultado não foi aleatório, uma vez que o $p$-valor foi menor que 0,05 para as legendas com tu e com você. No teste realizado a partir do Programa $\mathrm{R}$ analisamos a notas atribuídas por tipo de relação com os dados de tu e você separadamente. Nos dois casos o teste estatístico indicou diferenças significativas $(p<0,05)$ : para tu-simétrico vs. tu-assimétrico o $p$-valor foi de 0.0002007 e para você-simétrico vs. você-assimétrico foi de 0.002265 . Confirmamos assim que o tipo de relação interferiu no julgamento das formas de 2 SG no experimento realizado em Lisboa.

Antes de analisar outros aspectos que podem ter influenciado nesse resultado do experimento feito em Lisboa, vejamos o gráfico 2 do experimento realizado no Rio de

\footnotetext{
${ }^{16}$ A formula do programa R utilizada foi: wilcox.test (NOTA Relação) com os dados de tu e com os de voce ${ }^{\wedge}$
} separadamente. Estamos chamando de "Relação" a oposição entre contextos simétricos vs. assimétricos. 
Janeiro. É possível observar que há padrões bem nítidos de comportamento diferenciando a reação/avaliação dos participantes de origem portuguesa e brasileira para as formas tu e você das legendas analisadas:

Gráfico 2: Julgamento dos participantes do Rio de Janeiro para as formas de $2 S G$ em função do tipo de relação:

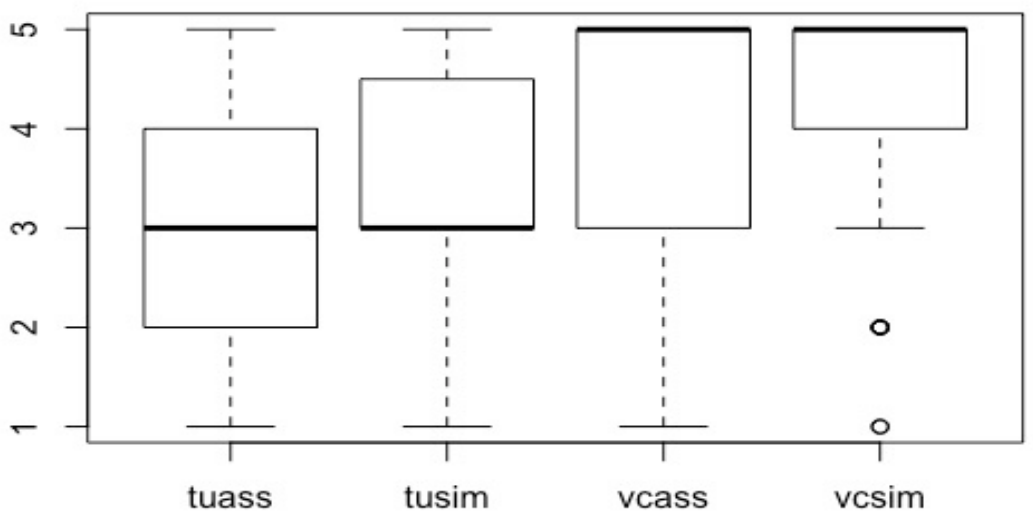

Fonte: Adaptado de Lopes, Oliveira e Carvalho (2016, p. 126)

Se observarmos os resultados do experimento realizado no Rio de Janeiro ilustrado no gráfico 2, é possível perceber que os gráficos 1 e 2 apresentam um comportamento inversamente proporcional. No Rio de Janeiro, diferentemente do que ocorreu em Lisboa, foi o pronome você, e não $t u$, que teve uma boa avaliação em relação a $t u$. As medianas estão no topo da escala (nota 5) nos 2 tipos de relação para as legendas com você. O pronome $t u$ apresentou uma mediana de 3 também nos dois tipos de relação. Os dados de tu-simétrico apresentaram uma dispersão das notas em direção à nota 4, enquanto o tu-assimétrico teve notas entre 2 e 4 . A forma você nos dois tipos de relação obteve sempre notas altas no PB: acima de 3 nas cenas de relação assimétrica e entre 4 e 5 nas de simétrica.

Comparando os gráficos 1 e 2, percebemos padrões visuais bastante semelhantes se forem observados como uma proporção inversa: os resultados do experimento legendado para tu no PE (gráfico 1) correspondem ao que fora observado para você no PB (gráfico 2), da mesma forma que os resultados de você no PE correspondem aos resultados de tu no PB. Quer isso dizer que a aceitação pelos falantes do PE e do PB (representados respectivamente por Lisboa e Rio de Janeiro) das formas variantes de segunda pessoa é, por assim dizer, oposta ou contrária. Enquanto a forma tu é bem avaliada com notas altas no PE nas relações simétricas e assimétricas, no Brasil (em particular, entre os falantes do Rio de Janeiro), foi a forma você que obteve as notas mais altas.

Na próxima seção, comentaremos brevemente os resultados relativos ao fator etário 
(sem significância estatística) e, na sequência, analisaremos os padrões de frases com a análise das frequências e do p-valor.

\subsection{A atuação do fator etário}

Como mencionado anteriormente, procurou-se estabelecer uma distribuição por quatro faixas-etárias com nove anos de diferença entre elas: F1 (de 15 a 24 anos), F2 (de 25 a 34 anos), F3 (de 35 a 44 anos) e F4 (mais de 45 anos). A distribuição por gênero não foi equilibrada, pois conseguimos mais mulheres do que homens para realizar o teste. A nossa hipótese era a de que os mais jovens apresentariam uma avaliação mais positiva para você nas relações assimétricas como defendem Nascimento, Mendes, Duarte (2018, p. 261).

Os gráficos de 3 a 6 confrontam os resultados tendo em vista o tipo de relação (simétrica e assimétrica) e a forma empregada no experimento por faixa etária. As colunas dos gráficos correspondem às faixas etárias (de F1 a F4) e as notas são indicadas por diferentes cores em cada coluna com os percentuais para os quatro grupos etários:

Gráfico 3. Frequências das notas dadas a tu-simétrico por faixa etária (Lisboa)

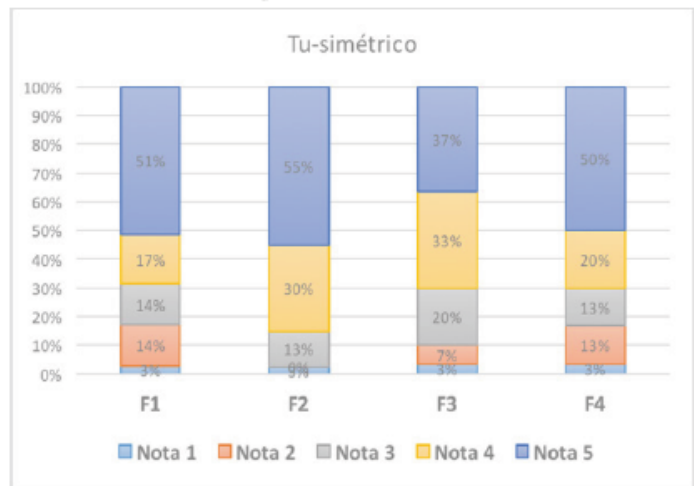

Gráfico 5. Frequências das notas dadas a tu-assimétrico por faixa etária (Lisboa)

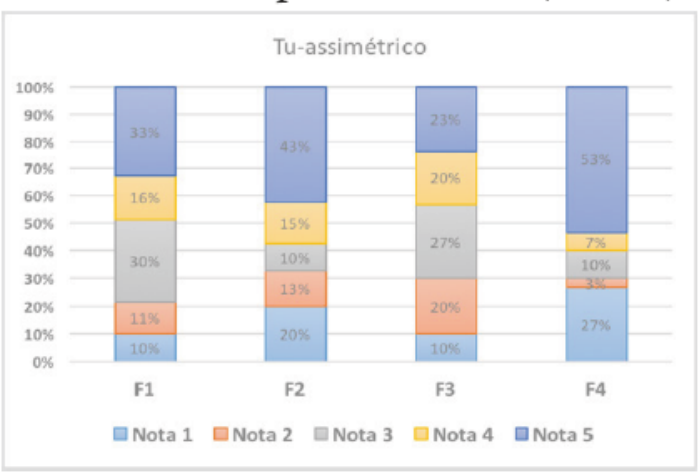

Gráfico 4. Frequências das notas dadas a você-simétrico por faixa etária (Lisboa)

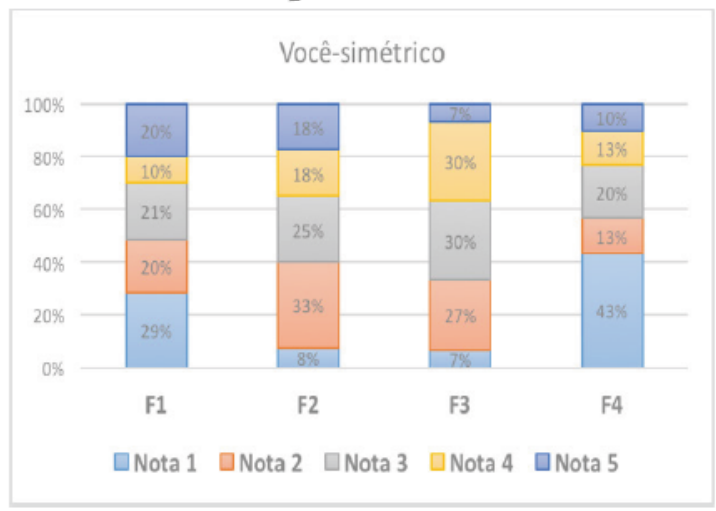

Gráfico 6. Frequências das notas dadas a você-assimétrico por faixa etária (Lisboa)

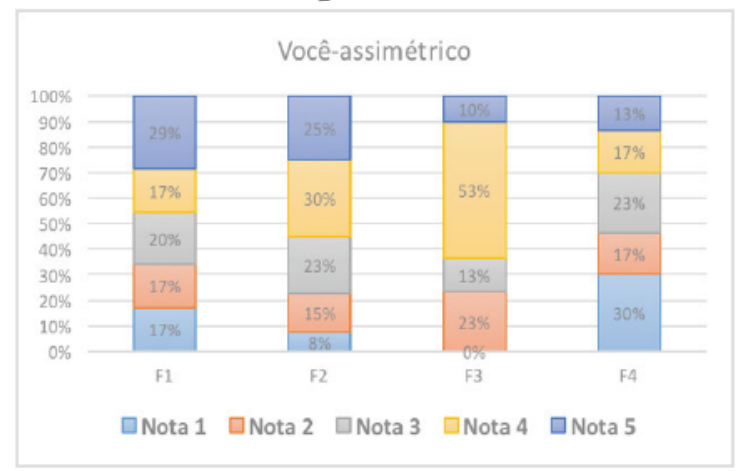

Fonte: Elaborado pelas autoras. 
Ao observar as notas atribuídas ao tratamento tu (gráficos 3 e 5), nota-se que não houve discrepâncias entre os participantes de diferentes idades, pois a maioria reagiu positivamente ao seu emprego atribuindo a nota mais alta nos dois contextos: entre $40 \mathrm{e}$ $50 \%$ para a nota 5 . Houve, entretanto, um grupo que destoou ligeiramente dos demais. Trata-se dos participantes da faixa 3 que são os que têm entre 35 e 44 anos de idade. Diferentemente dos demais, estes participantes, por assim dizer adultos, tiveram um comportamento mais oscilante, particularmente, com as cenas de $t u$-assimétrico. Neste contexto, os percentuais apresentam-se com valores próximos de $20 \%$ para as notas de 2 a 5 , o que demonstra algum tipo de estranhamento quanto às cenas avaliadas. Outro resultado curioso do gráfico 5 ( $t u$-assimétrico) é a alta aceitação de tu na faixa etária mais velha (F4 com 53\% de nota máxima).

A rejeição ao tratamento você, como vimos, foi bastante relevante em termos gerais e se confirma em todas as faixas etárias (gráficos 4 e 6). Há, entretanto, alguma irregularidade nas notas por faixa etária que pode sinalizar para uma mudança de comportamento da comunidade. Se observarmos a diferença entre as notas extremas ( 1 como pior avaliação e 5 como melhor avaliação da cena), nota-se que as faixas etárias também extremas da escala (os mais jovens contra os mais velhos) apresentaram um comportamento um tanto diverso. Aparentemente os mais jovens rejeitaram menos você se comparados aos mais velhos nos dois contextos. No gráfico 4 do você-simétrico, em termos comparativos, os mais jovens reagiram de maneira menos negativa a você do que mais velhos se forem observadas as notas mais altas e mais baixas dos dois grupos: $20 \%$ dos mais jovens atribuíram nota máxima (5) contra $10 \%$ dos mais velhos e estes mesmos jovens atribuíram $29 \%$ contra $43 \%$ dos mais velhos para a nota mais baixa (1). Aparentemente os mais velhos rejeitaram muito você, ao passo que os mais jovens, nem tanto assim.

Nas relações assimétricas (gráfico 6), deu-se o mesmo. Os mais jovens aceitaram mais do que os mais velhos ( $29 \%$ contra $13 \%$ para nota 5 ) e rejeitaram menos ( $17 \%$ contra $30 \%$ para nota 1$)$.

Embora seja prematuro atribuirmos uma mudança de comportamento por conta de não termos ainda resultados substanciosos, os resultados do experimento parecem nos dar alguns indícios que a geração mais nova dos lisboetas não reage tão mal ao emprego de você quanto as gerações de pessoas mais velhas.

\subsection{As estruturas linguísticas: os cinco padrões postulados para tu e você}

Com o intuito de observar mais claramente a reação do participante à forma em si, foram propostas estruturas linguísticas que (a) efetivamente favorecessem a presença ex- 
plícita de você e tu em contextos de variação e (b) claramente estabelecessem uma distinção entre sujeito nulo e pleno. Tal perspectiva foi adotada não só porque o $\mathrm{PE}$, ao contrário do $\mathrm{PB}$, é uma língua de sujeito nulo, mas também para que o experimento (i) permitisse identificar ora o julgamento da forma explícita $(t u$ ou você $)$ ora o julgamento das formas verbais associadas a eles, uma vez que, por hipótese, a desinência verbal de terceira pessoa (ou desinência zero) não teria necessariamente o valor negativo presente em você; (ii) possibilitasse nova a aplicação do teste com os falantes do $\mathrm{PB}$ que na maioria das localidades não realizam a concordância canônica de $2^{\mathrm{a}}$ pessoa entre tu e o verbo em estruturas como: $t$ ufazes/fizeste, etc. Para este último ponto, cabe ressaltar que tanto a presença quanto a ausência da desinência verbal de $2^{a}$ pessoa do singular poderia causar estranhamento aos falantes do $P B$. No primeiro caso, a presença das marcas desinenciais de 2SG (tu fazes) tem taxas de uso bastante baixas na maioria das localidades em que se usa $t u$, além do fato de existirem marcas locais próprias e bem pontuais ${ }^{17}$. No segundo caso, ou seja, a falta da desinência de $2^{\text {a }}$ pessoa ou a falta da concordância canônica nas legendas também poderia causar reação negativa dos participantes pelo fato de se tratar de um texto escrito (mesmo que seja uma legenda de um vídeo). A ausência da concordância verbal convencional é um fenômeno linguístico ainda estereotipado socialmente no PB e, em função desse aspecto, não se teria como avaliar se o julgamento do participante estaria centrado na forma pronominal $(t u)$ ou na forma do verbo (fazes/faz). Assim, por motivos diferentes, procurou-se controlar também no experimento ora o foco no pronome ora o foco no verbo, como será mostrado adiante.

Foram então previstos os seguintes padrões sintáticos para cada condição experimental, privilegiando a presença das formas variantes tu e você na posição de sujeito, ou não, em alguns padrões postulados. Seguem os padrões sintáticos e as frases de cada estrutura postulada com o código ${ }^{18}$ do dado experimental ao lado do exemplo:

Padrão 1: Construções de tópico-comentário com uma das formas variantes, como pronomes fortes, em posição de tópico:

\section{$\mathrm{Tu}$, doente da garganta? Que tolice! (tuass04) \\ Tu... A Rita não está a sair com o chefe por amor. (tusim04) \\ Você, inocente? Todos os presos dizem o mesmo. (vcass01) \\ Você, ao meu lado... para sempre. (vcsim04)}

\footnotetext{
${ }^{17}$ Em Pernambuco e em outras localidades brasileiras, por exemplo, pode ocorrer uma forma alternativa para a desinência de $2^{a}$ pessoa no pretérito perfeito: Tu fosse ao cinema ontem (no lugar de Tu foste ao cinema ontem), como mostraram Scherre et al (2015), mas tal variante também é pouco produtiva e reconhecida como marca local.

${ }^{18}$ Os dados codificados constam do anexo 1 . O código de cada dado indica se é um item experimental tu ou você $(v c)$, seguido pelo tipo de relação (assimétrico abreviado como ass e simétrico como sim) e por fim, o número do item experimental.
} 
Padrão 2: Construções de elipse, sejam coordenadas sejam estruturas comparativas em ambos os casos com verbo elíptico:

Nós somos honestos... mas tu não (és). (tuassim03)

Assim, ficarei tão feliz quanto $t u$ (fiearás). (tusim03)

Sou tão culpado do crime quanto você (é). (vcass03)

Não sou doente como você (é). (vcsim02)

Padrão 3: Construção em que o pronome aparece dentro do sintagma nominal, com adjunto, mas não tem nenhuma relação sintática com o verbo:

[Nem $t u$, nem ninguém]SUJ pode mudar de lugar agora. (tuass01)

[Ninguém, nem $t u$,] SUJ vai conseguir casar com ele. (tusim05)

A sua mãe, o seu pai e até você, todos morreremos um dia. (vcass02)

$\mathrm{E}$ [os rapazes, inclusive você,] SUJ levaram com a culpa. (vcsim05)

Padrão 4: Construções com sujeito pleno em que o pronome aparece focalizado com operadores:

E tu mesma podes guardar-me as compras. (tuass04)

Nem tu sabes do que sou capaz! (tusim02)

Só você para achar que acreditei nessa história. (vcass05)

Foi você mesmo que nos disse. (vcsim01)

Padrão 5: Construções com sujeito nulo:

Por acaso, sabes quem sou eu? (tuass05)

Volta aqui! Vais-te arrepender! (tusim01)

... é impossível, só pode estar louca! (vcass04)

Sabe que eu tenho que estudar. Tem que perceber isso! (vcsim03)

Os resultados estão indicados nos gráficos 7-10. Os valores percentuais das notas dadas a cada padrão estão no eixo $x$ e os padrões estão indicados por diferentes cores nas legendas. 
Gráfico 7. Frequências das notas dadas a tu-simétrico por padrão estrutural (Lisboa)

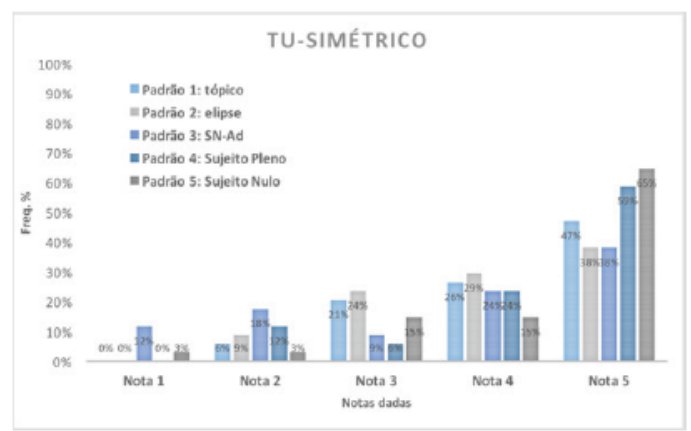

Gráfico 9. Frequências das notas dadas a tu-assimétrico por padrão estrutural (Lisboa)

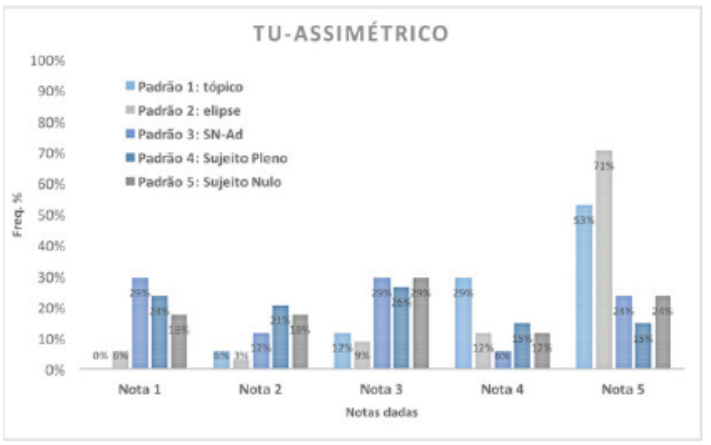

Gráfico 8. Frequências das notas dadas a você-simétrico por padrão estrutural (Lisboa)

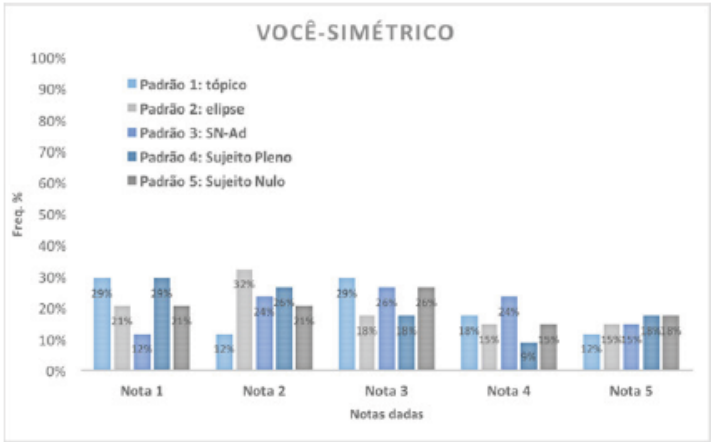

Gráfico 10. Frequências das notas dadas a você-assimétrico por padrão estrutural (Lisboa)

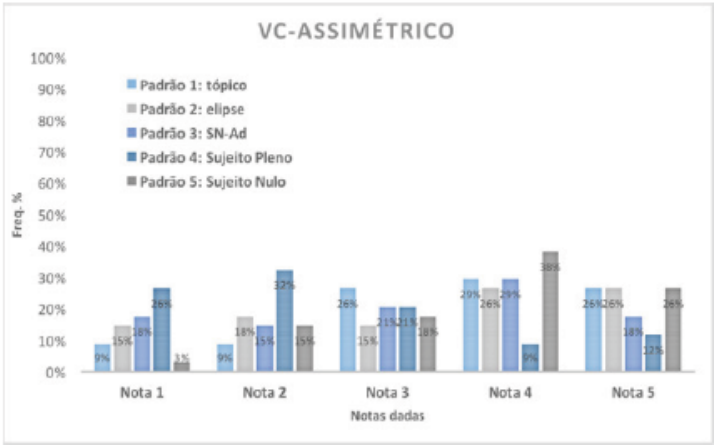

Fonte: Elaborado pelas autoras.

Os resultados apresentados nos gráficos de 7 a 10 são mais complexos, mas há aspectos bastante regulares que podem levar a certas generalizações. Aparentemente, nas relações simétricas (gráficos 7 e 8), os padrões sintáticos não interferiram sobremaneira nos resultados, uma vez que nos contextos previstos como tu-simétrico (gráfico 7) todos os padrões sintáticos postulados apresentaram índices altos de frequência regulares e semelhantes para a nota máxima (5). Houve, entretanto, uma leve rejeição para os padrões 2 e 3.

Para o você-simétrico (gráfico 8 ), o comportamento observado também foi bem equivalente, só que agora com notas baixas em todos os padrões sintáticos previstos. No gráfico 8 , observa-se que os índices de frequência ficam em torno dos $20 \%$ nas notas mais baixas da escala (de 1 a 3), ou seja, a forma você foi rejeitada em tal contexto independentemente das estruturas em que ocorria. 
Nos contextos considerados como assimétricos (gráficos 9 e 10), os padrões sintáticos previstos geraram resultados um tanto discrepantes entre os participantes portugueses, não necessariamente influenciados pela estrutura em si, mas talvez pelo contexto da relação. Uma análise mais detalhada dos dados submetidos ao julgamento dos participantes pode elucidar os aspectos que interferiram nesses resultados.

As frases para tu-assimétrico tiveram notas bem altas (acima de 50\%) para os padrões 1 (tópico) e 2 (elipse do verbo), exemplificado em (10) e (11), mas houve incerteza para os padrões 3, 4 (sujeito pleno focalizado) e 5 (sujeito nulo), ilustrados de (12) a (14), que apresentaram frequências em torno de $20 \%$ para as notas 3 e até mesmo nota 1:

(10) Tu, doente da garganta? Que tolice!

(11) Nós somos honestos... mas tu não.

(12) Nem $t u$, nem ninguém pode mudar de lugar agora.

(13) E tu mesma podes guardar-me as compras.

(14) Por acaso, sabes quem sou eu?

Acreditamos que a divergência possa estar associada mais ao contexto de uso do pronome na legenda do que à estrutura em si. Vejamos a análise desses dados experimentais (10-14):

Em (10), o diálogo é travado entre um adulto e uma criança em uma relação assimétrica em termos etários, mas de forte proximidade no que se refere ao contato, vivências comuns, compromisso afetivo, etc. Trata-se de um adulto que está oferecendo um gelado (sorvete no PB) a um menino dentro de uma casa. Tal contexto favorece o emprego de $t u$. Em (15), temos as legendas completas da cena e na figura 02 :

(15) Adulto: E aí, miúdo! Que tal um gelado?

Adulto: Está uma delícia!

Adulto: Tenho aqui mais um!

Garoto: Não, obrigado! Tenho medo de ficar doente da garganta.

Adulto: Ora!

Adulto: Tu, doente da garganta? Que tolice! 
Figura 02. Sequência das cenas relativas a um tu-assimétrico com um dado experimental de padrão 1 (construções de tópico-comentário)
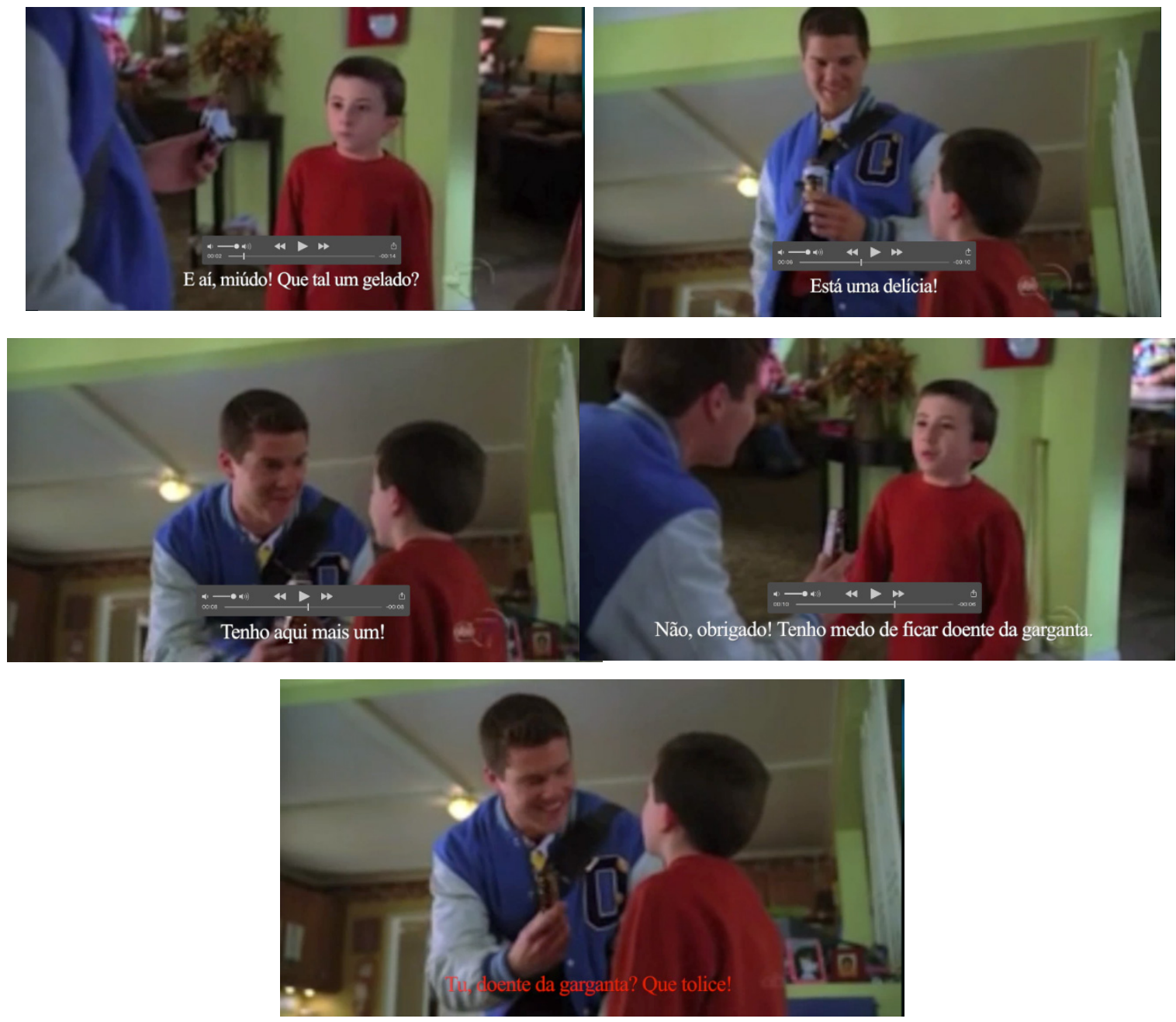

Fonte: Cenas recortadas do YouTube para montagem do experimento.

O dado experimental (11), reproduzido de maneira completa dentro da cena, em (16), está inserido em um diálogo estabelecido entre dois homens numa interação profissional em uma sala reservada, aparentemente um escritório. Visualmente na cena há uma relação transacional, segundo Briz (2004, p. 80), pois o papel funcional dos interactantes está mais sujeito a convenções sociais. A natureza da conversa, uma espécie de negociata financeira, acaba por dar, entretanto, um caráter de proximidade ou cumplicidade entre os interactantes em termos da identidade de grupo, marcada até mesmo pela repreenda que ocorre no diálogo. Consideramos que também neste caso temos um contexto propício ao emprego de tu: 
(16) Homem 1: O que foi decidido na reunião?

Homem 2: Os empresários querem trinta mil. Ofereci-lhes vinte mil. Prometi pagar o restante depois. Desconfiaram... garanti-lhes que somos honestos.

Homem 1: Nós somos honestos... mas tu não.

Diferentemente dos dois casos anteriores, a frase do padrão 3, ilustrada em (12), gerou certa insegurança e rejeição entre os participantes portugueses. Neste caso, tanto o contexto quanto a estrutura podem ter atuado simultaneamente na sua rejeição observada entre os participantes do julgamento. Na cena completa, reproduzida, em (17), a forma tu ocorre em uma conversa de uma comissária de bordo com um passageiro. Diferentemente dos contextos anteriores, todos os parâmetros são de distância comunicativa que é desfavorecedora do tratamento tu em uma situação assimétrica prototípica: [- proximidade], [- vivências comuns], [- compromisso afetivo], [- identidade grupal], etc.

(17) Aeromoça: Há algum problema com a cadeira?

Passageiro: Não gostei deste lugar. Quero trocar.

Aeromoça: Não é permitido mudar os passageiros de lugar.

Passageiro: Mas há cadeiras livres.

Aeromoça: Regras são regras.

Aeromoça: Nem tu, nem ninguém pode mudar de lugar agora.

Os dados experimentais (13) E tu mesma podes guardar-me as compras e (14) Por acaso, sabes quem sou eu? podem ter sido rejeitados por estarem associados a um contexto marcadamente assimétrico que é desfavorecedor de $t u$. Em (13), tem-se uma ordem inusitada de uma cliente a uma funcionária de uma loja e, em (14), um motorista se dirige rispidamente à abordagem policial.

Em suma, como quisemos mostrar analisando o contexto de uso de cada cena, consideramos que a divergência entre as notas atribuídas aos dados experimentais de tu-assimétrico estão mais associadas ao tipo de relação do que propriamente ao padrão estrutural em si.

No caso das frases com você-assimétrico, o padrão estrutural pode ter tido maior atuação nos resultados. No geral, as frequências foram oscilantes em todas as notas, mas identificam-se frequências um pouco mais altas para o padrão 5 do sujeito nulo (nota 4 
com $38 \%$ e 5 com 26\%) e forte rejeição para o padrão 4 do sujeito pleno focalizado (nota 1 e 2, respectivamente com, 26\% 32\%). Embora seja um experimento piloto, os resultados confirmaram as hipóteses de outros trabalhos sobre o valor negativo do tratamento você no português europeu, além da não-associação obrigatória entre você e a forma verbal na terceira pessoa: no $\mathrm{PE}$ o sujeito nulo de $3^{\text {a }}$ pessoa não é negativamente marcado e não necessariamente relacionado ao tratamento você por conta do uso de formas nominais ou prenomes para o tratamento da segunda pessoa, como, A menina/Fulana quer café? (cf. LEŠKOVÁ, 2012; GUILHERMO; BERMEJO, 2015).

Pelo fato do PE ser uma língua de sujeito nulo, diferentemente do PB, que tende a preencher o sujeito ${ }^{19}$, resolvemos analisar a reação dos participantes tendo em vista os dados de sujeito pleno focalizado e nulo (padrões 4 e 5 ), principalmente para você, observando as diferenças de perfis sociais dos participantes. Cabe lembrar que, nas frases com sujeito expresso, os pronomes ( $t u$ ou você $)$ aparecem sempre focalizados com operadores para que a rejeição à construção fosse menor (o que não necessariamente surtiu efeito como veremos).

\subsection{Sujeito nulo vs. sujeito focalizado: diferenças estatísticas}

Nos gráficos 11 e 12 a seguir computamos apenas os dados experimentais dos padrões 4 e 5 (sujeito nulo e sujeito focalizado) por forma de $2 S G$ em cada tipo de relação. Embora o número de dados seja mais reduzido, os gráficos confirmam nossas previsões iniciais:

Gráfico 11: Distribuição das notas atri- Gráfico 12: Distribuição das notas atribuídas às frases do padrão 4 (sujeito fo- buídas às frases do padrão 5 (sujeito calizado) em Lisboa nulo) em Lisboa
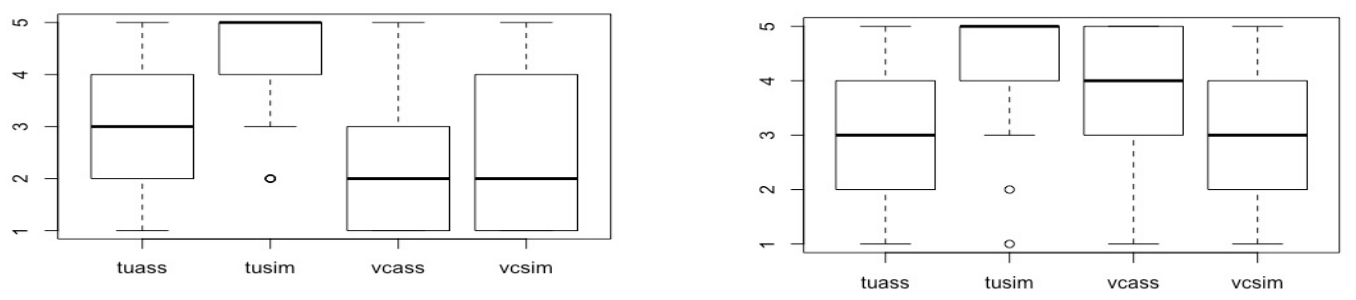

Fonte: Elaborado pelas autoras.

\footnotetext{
19 Para maiores detalhes, ver Duarte (2018) entre outros trabalhos que discutem o PB como língua de sujeito nulo parcial.
} 
No gráfico 11 que representa os julgamentos das frases com sujeito focalizado, vemos uma diferença entre os resultados relativos a tu e a você. No primeiro caso, a mediana para as legendas que traziam tu em cenas de relação simétrica atingiu o ponto máximo da escala 5, enquanto nas cenas com assimetria as legendas de tu obtiveram um julgamento mais neutro (mediana 3). Os julgamentos para você nos dois contextos atingem medianas bem mais baixas (mediana 2). O gráfico 12 referente aos julgamentos de frases de sujeito nulo apresenta um resultado idêntico para as legendas com tu se comparado com o gráfico 11. Entretanto, os julgamentos para você são completamente diferentes e mostram medianas bem mais altas, principalmente, para as cenas de assimetria (mediana 4).

Assim, nota-se que não houve diferença entre os julgamentos para as legendas com tu seja em frases com sujeito nulo e sujeito pleno focalizado, mas os julgamentos para você foram distintos: rejeição em frases de sujeito focalizado e aprovação em frases de sujeito nulo. A análise estatística feita com o teste $W i l_{c o x o n}{ }^{20}$ confirmam que essas diferenças são significativas para você $(\mathrm{p}$-valor $=0.001194)$ e não para $t u(p$-valor $=0.4375)$ nas frases nulas e plenas.

Enquanto no gráfico 1, com todos os julgamentos das frases, as medianas para as legendas com você eram neutras (mediana 3 ) em cenas com simetria e assimetria, os gráficos relativos aos sujeitos focalizados e nulos mostraram que a aceitação do sujeito nulo foi bem maior do que a do sujeito focalizado para você nas duas relações. O você-nulo, ou melhor dizendo, a forma verbal na terceira pessoa do singular é mais bem avaliada nas relações assimétricas do que nas simétricas com médias que atingem o ponto máximo da escala. A forma plena do pronome você, entretanto, desencadeia outro tipo de reação entre os participantes, uma vez que as médias baixas configuram rejeição a legendas com você nas frases de sujeito focalizado.

Mesmo que ainda não sejam conclusivos, os experimentos reiteram, de certa forma, (1) uma rejeição ao emprego explícito de você para a segunda pessoa no PE; (2) o emprego do verbo na terceira pessoa sem sujeito preenchido não é necessariamente interpretado como "tratar alguém por você". Por tal razão, consideramos que, a variante sujeito nulo + verbo na $3^{a}$ pessoa não é negativamente marcado e não é uma correlata da variante você + verbo no $\mathrm{PE}$; (3) a forma verbal na terceira pessoa é uma estratégia bem aceita nas relações assimétricas; (4) a forma tu (como sujeito nulo ou focalizado) é bem avaliada nas relações simétricas.

${ }^{20}$ wilcox.test (NOTA ESTRUTURA-pleno-nulo) 


\section{CONSIDERAÇÕES FINAIS}

Os resultados preliminares obtidos a partir dos experimentos realizados em Lisboa dialogam com nossas hipóteses e previsões iniciais e apontam para novos caminhos de investigação:

a) a forma $t u$ apresentou julgamentos mais positivos dos participantes nos dois tipos de relação com médias mais altas nas relações simétricas;

b) a forma você, diferentemente do que ocorre, em geral, no Brasil, teve um julgamento negativo (média 3 ou abaixo de 3 ) nas cenas de diferentes relações interpessoais (simétricas, assimétricas), entre os falantes portugueses que participaram do experimento. Em termos comparativos, as avaliações foram levemente mais positivas (acima de 3 ) para cenas com relações assimétricas e entre os participantes mais jovens;

c) existe uma diferença quanto ao julgamento das formas de tratamento verbo-pronominais: verbo na segunda pessoa (2SG), verbo na terceira pessoa (3SG) e você (sujeito pleno) no português europeu;

d) aparentemente, a forma verbal de 3SG não seria correlata da variante você, pois apresenta aceitação positiva nas relações assimétricas, o que não ocorre necessariamente com o você explícito, como observado na comparação entre as frases do padrão 4 (sujeito focalizado) e 5 (sujeito nulo) analisadas estatisticamente com o teste Wilconx realizado no Programa R;

e) a análise da percepção/avaliação dos usos linguísticos pelo viés experimental, ainda que seja uma proposta piloto, mostrou-se frutífera, reiterando que uma perspectiva mais integrativa entre diferentes correntes teóricas pode auxiliar a sociolinguística no que concerne à questão da atuação do problema de avaliação nos processos de mudança linguística.

\section{REFERÊNCIAS}

BALSALOBRE, S. R. G. Brasil, Moçambique e Angola: desvendando relações sociolinguísticas pelo prisma das formas de tratamento. 2015. 345 f. Tese (Doutorado em Linguística e Língua Portuguesa) - Universidade Estadual Paulista Júlio de Mesquita Filho, Araraquara, 2015. Disponível em: http://hdl.handle.net/11449/127872. Acesso em: ?

BRIZ, A. Cortesía verbal codificada y cortesía verbal interpretada em la conversación. In: BRAVO, D.; BRIZ, A. Pragmática sociocultural - Estudios sobre el discurso de cortesía em español. Barcelona: Ariel, 2004, p. 67-93.

BROWN, R.; GILMAN, A. The pronouns of power and solidarity. SEBOOK, T. A. (Ed.). Style in language. Cambridge; Massachusetts: The MIT Press, 1960. 
CARREIRA, M. H. A. Modalisation Linguistique en Situation d'Interlocution. Proxémique verbale et modalités en portugais. 1995. Tese (Doutorado), Universidade de Paris IV, Sorbonne, 1995.

CARREIRA, M. H. A. Semântica e discurso, estudos de Linguística Portuguesa e Comparativa (Português/Francês). Porto: Porto Editora, 2001.

CARREIRA, M. H. A. La designation de l'autre en portugais européen: instabilités linguistiques et variations discursives. Instabilités linguistiques dans les langues romanes. Travaux et Documents, n. 16, p. 173-184, 2002.

CARREIRA, M. H. A. Les formes d'allocution du portugais européen: valeurs et fonctionnements discursifs. Franco-British Studies, p. 35-45, 2004. Disponível em: http://cvc.cervantes.es/obref/coloquio_paris/ponencias/pdf/cvc_araujo.pdf. Acesso em: 02 fev. 2008.

COHEN J.D.; MACWHINNEY B./ FLATT M.; PROVOST J. PsyScope: A new graphic interactive environment for designing psychology experiments. Behavioral Research Methods, Instruments, and Computers, 25(2), 257-271, 1993.

CINTRA, L. F. L. Sobre « formas de tratamento » na língua portuguesa. Lisboa: Livros Horizonte, 1972.

DERWING, B. L. \& DE ALMEIDA, R. G. Métodos experimentais em Linguística. In: MAIA, M.; FINGER, I. (Eds.). Processamento da Linguagem. Pelotas: Educat, 2005, p. 401-442.

DUARTE, M. E. L. O sujeito nulo no português brasileiro. In: CYRINO, S.; MORAIS, Maria A. Torres. História do Português Brasileiro: mudança sintática do português brasileiro: perspectiva gerativista. São Paulo: Contexto, 2018.

DUARTE, I. M.. Formas de tratamento em português: Entre léxico e discurso. Revista Matraga, Rio de Janeiro, v.18 (28): 84-104, jan./jun. 2011.

FARIA, R. F. N. O Fenómeno da Delicadeza Linguística em Português e em Inglês. 2009. Tese (Doutorado em Linguística). Faculdade de Ciências Sociais Humanas, UCP, 2009.

GUILHERME, A. R. B.; BERMEJO, V. L.. Quão cortês é você? O pronome de tratamento você em Português Europeu. Labor-Histórico, Rio de Janeiro, 1 (2): 167-180, jul.-dez, 2015.

GYULAI, É. V. G. Abordagem das Formas de Tratamento nas Aulas de Português Língua Segunda/Língua Estrangeira. 2011. Dissertação (Mestrado), Universidade do Porto, 2011.

HAMMERMÜLLER, G. Die Anrede im Portugiesischen. Eine soziolinguistiche Untersuchung $z u$ Anderkonventionen und Portugiesischen. 46 (L'adresse en portugais. Une recherche sociolinguistique des conventions et des formes d'adresse du portugais européen contemporain. Uma análise sobre a complexidade de sistema das formas de tratamento em Português - tradução de Carreira). Tese (Doutorado), Universidade de Kiel, 1993. 
KENEDY, E. Psicolinguística na descrição gramatical. In: MAIA, M. (Org.). Psicolinguística, psicolinguísticas. Rio de Janeiro: Contexto, 2015, p.143-156.

LABOV, W. The social stratification of English in New York. Washington, D. C.: Center for Applied Linguistics, 1966.

LEŠKOVÁ, Jana. As formas de tratamento em Português Europeu. Olomouc. Diplomová práce (Mgr.). UNIVERZITA PALACKÉHO V OLOMOUCI. Filozofická fakulta, 2012.

LOPES, C. R. dos S. Retratos da mudança no sistema pronominal: o tratamento carioca nas primeiras décadas do século XX. In: CORTINA, A.; NASSER, S. M. G. C. (Orgs.). Sujeito e Linguagem: Séries Trilhas Linguísticas. Araraquara: Cultura Acadêmica, 2009, v.17, p. 47-74.

LOPES, C. R. dos Santos; CAVALCANTE, S. A cronologia do voceamento no português brasileiro: expansão de você - sujeito e retenção do clítico-te. Revista Lingüistica, Madrid, v.25, p.30-65, 2011.

LOPES, C. R. dos S.; MARCOTULIO, L. L.; SANTOS, V. M., SILVA, A. S. Quem está do outro lado do túnel? Tu ou você na cena urbana carioca. In: Neue Romania des Instituts für Romanische Philologie der FU Berlin, v.39, 2009, p.49-66.

LOPES, C. R. dos S.; SANTOS, V. M. Variation of 2nd person pronouns in Rio de Janeiro/ Brazil: Social stratification in large cities. Paper presented at Sociolinguistics Symposium 19 Language and city, Freie Universität Berlin, 2012.

MACHADO, A. C. M. A implementação de "você" no quadro pronominal: as estratégias de referência ao interlocutor em peças teatrais no século XX. 2006. 108 f. Dissertação (Mestrado em Letras Vernáculas) - Universidade Federal do Rio de Janeiro, Rio de Janeiro, 2006.

MAIA, Marcus; FINGER, Ingrid. Processamento da linguagem. Pelotas: Educat, 2005.

MARQUES, Maria Emília Ricardo. Complementação verbal. Estudo sociolinguístico. 1988. Tese (Doutorado), Universidade Nova de Lisboa, Lisboa, 1988.

MEDEIROS, S. M. de O. A Model of Address From Negotiation: a Sociolinguistic Study of Continental Portuguese. Tese (Doutorado), Universidade do Texas, Texas, 1985.

NASCIMENTO, M. F. BACELAR, MENDES, Amalia; DUARTE, Maria Eugenia. Sobre formas de tratamento no português europeu e brasileiro. Diadorim, Rio de Janeiro, vol. 20 - Especial, p. 245-262, 2018.

OLIVEIRA, T. L.; LOPES, C. R. S; CARVALHO, B. B. A expressão da $2^{\text {a }}$ pessoa do singular em cenas legendadas: variação e percepção numa abordagem experimental. Revista Todas as Letras. São Paulo, v. 18 (2), 2016, p.117-132.

OUSHIRO, L. Identidade na pluralidade: avaliação, produção e percepção linguística na cidade de São Paulo. 2015.395 f. Tese (Doutorado em Linguística), Universidade de São Paulo, São Paulo, 2015. 
PAREDES SILVA, V. L. A variação você/tu na fala carioca. Comunicação apresentada no $1^{\circ}$ Encontro de Variação Linguística do Cone Sul. Universidade Federal do Rio Grande do Sul, Setembro de 1996.

PAREDES SILVA, V. L. O retorno do pronome $t u$ à fala carioca. In: RONCARATI, C.; ABRAÇADO, J. (Orgs.) Português Brasileiro: contato linguístico, heterogeneidade e história. Rio de Janeiro: 7 letras, 2003, p. 160-169.

RUMEU, M. C. de B. A implementação do 'você' no português brasileiro oitocentista e novecentista: um estudo de painel. 2008. 928f. Tese (Doutorado em Língua Portuguesa) - Universidade Federal do Rio de Janeiro, Rio de Janeiro, 2008.

SANTANA, É. E. da P.; CARDOSO, S. A. Os pronomes tu e você para identificação do interlocutor: capitais do sudeste brasileiro com base nos dados do Projeto ALiB. In: ISQUERDO, A. N.; ALTINO, F. C.; AGUILERA, V. de A. (Org.). Atlas Linguístico do Brasil: descrevendo a língua, formando jovens pesquisadores. Vol. III, Londrina: UEL, 2014, CDROM.

SANTOS, V. M. dos. "Tu vai para onde?... Você vai para onde”: manifestações da segunda pessoa na fala carioca. 2012. 137 f. Dissertação (Mestrado em Língua Portuguesa) Universidade Federal do Rio de Janeiro, Rio de Janeiro, 2012.

SCHERRE, M. et al. Variação dos pronomes 'tu' e 'você'. In: MARTINS, M. A.; ABRAÇADO, J. (Orgs.). Mapeamento sociolinguístico do português brasileiro. São Paulo: Contexto, 2015, p. 133-172.

SCHÜTZE, C. T.; SPROUSE, J. Judgement data. In: PODESVA R.; DEVYAN; SHARMA (Eds.). Research methods in linguistics. New York: Cambridge University Press, 2013, p. 27-50.

WEINREICH, U.; LABOV, W.; HERZOG, M. Fundamentos empíricos para uma teoria da mudança linguística. Trad. de Marcos Bagno. São Paulo: Parábola, 2006 [1968].

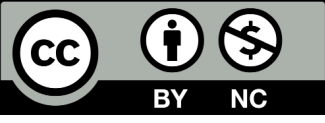

Data de submissão: 16/11/2018

Data de aceite: 17/09/2019 


\section{ANEXO 1: Frases experimentais}

\section{Pronome tu: relações assimétricas}

tuass01 [11] aeromoça-passageiro

Aeromoça: Há algum problema com a cadeira?

Passageiro: Não gostei deste lugar. Quero trocar.

Aeromoça: Não é permitido mudar os passageiros de lugar.

Passageiro: Mas há cadeiras livres.

Aeromoça: Regras são regras.

Aeromoça: Nem tu, nem ninguém pode mudar de lugar agora. $(\mathrm{Al})=\mathrm{AD}$

tuass02 [15] conversa-do-picolé -

Adulto: E aí, miúdo! Que tal um gelado?

Adulto: Está uma delícia!

Adulto: Tenho aqui mais um!

Garoto: Não, obrigado! Tenho medo de ficar doente da garganta.

Adulto: Ora!

Adulto: Tu, doente da garganta? Que tolice! A2

tuassim03- 28 - reunião de negócios

Homem 1: O que foi decidido na reunião?

Homem 2: Os empresários querem trinta mil. Ofereci-lhes vinte mil. Prometi pagar o restante depois. Desconfiaram... garanti-lhes que somos honestos.

Homem 1: Nós somos honestos... mas tu não.

tuass04 - [35] supermercado

Caixa: Não aceitamos cartão de crédito.

Cliente: O quê?

Caixa: Pagamento só em dinheiro.

Cliente: Não me diga!

Cliente: Não sabia que não aceitavam cartão.

Cliente: Volto depois...

Cliente: E tu mesma podes guardar-me as compras.

tuass05 - [39]policial-e-motorista

Policial: Passar o sinal vermelho é uma infração grave.

Policial: E num cruzamento perigoso como este...

Policial: Vou multá-lo!

Policial: Desculpe lá, mas é o meu trabalho!

Motorista: Eu estava atrasado para uma reunião.

Policial: Não interessa. Lei é lei!

Motorista: Como é que é?

Motorista: Por acaso, sabes quem sou eu? 


\section{Pronome tu: relações simétricas}

tusim01 [16] briga-apto

Homem: Acho que devemos separar-nos.

Mulher: Concordo... a minha paciência esgotou-se!

Mulher: Uma sogra não pode interferir na vida do casal!

Homem: Mentira!

Mulher: Está a arruinar o nosso casamento!

Homem: Adeus!

Mulher: Volta aqui! Vais-te arrepender!

tusim02 - cadeia-detentos

Detento: Eles vão pagar caro por me porem aqui.

Vou acabar com eles.

Não restará nenhum vivo.

Detento 2: Para de planear mais crimes.

Não vês que estás no fundo do poço?

Detento 1: Juro que vou sair daqui!

Vingo-me de todos!

Não me interessa nada. Só quero vingança!

Detento 2: Acabou-se! Matarei todos os traidores!

Detento 1: Não ficarei aqui!

Detento 2: Eles escaparam.

Cala-te!

Nem tu sabes do que sou capaz!

tusim03 - [22] praia-casal

Rapaz: Sabes, Júlia, eu estive a pensar...

Conhecemo-nos há tanto tempo ...

Estamos sempre juntos

um a ajudar o outro...

Moça: É verdade! Estamos sempre juntos....

Rapaz: Não percebo por que ainda não somos namorados.

Moça: Estou à espera que me peças em namoro.

Assim, ficarei tão feliz quanto tu.

tusim04 [29] escritório

H1: A Rita da Tesouraria anda a sair com o chefe...

$\mathrm{H} 2$ : Ah...toda a gente sabe que ele até dorme em casa dela!

Há pessoas que fazem de tudo para ascender na carreira...

H1: Sim...mas a Rita. Ela nunca faria isso.

Tu... A Rita não está a sair com o chefe por amor.

tusim05 (5) [36] mulheres-no-bar 
M1: O Caio telefonou-me ontem

Queria saber como eu estava...

...conversamos melhor...

...há chances de voltarmos...

M2: $\quad$ Posso parecer insensível

Mas...

Ninguém, nem tu, vai conseguir casar com ele.

\section{Pronome você: relações assimétricas}

vcass01 - advogada-prisioneiro

Advogada: Michel, conte-me a verdade.

Preso: Eu não fiz nada.

Advogada: Você, inocente? Todos os presos dizem o mesmo. A2

vcass02 - [21] hospital-medico-paciente

Paciente: Quanto tempo ainda tenho?

Médico: É muito cedo para uma resposta definitiva.

Paciente: Sei que o meu estado é grave.

Médico: Descanse um pouco.

Médico: É melhor não pensar nisso agora.

Paciente: Pode falar, Doutor.

Paciente: Prefiro saber a verdade.

Médico: A sua mãe, o seu pai e até você, todos morreremos um dia

vcass03 - [26] detetive-presidiário

Advogado: Saiu a sua condenação.

Preso: Não pode ser.

Preso: Eu não matei aquela mulher.

Advogado: As provas são incontestáveis.

Preso: Sou tão culpado do crime quanto você.

vcass04 - [37] pedindo na lanchonete

Atendente: Olá! Posso ajudar?

Cliente: Quero o menu de hambúrger e batatas fritas com refrigerante.

Atendente: Sinto muito. Essa promoção acabou ontem.

Cliente: Acabou como?

Atendente: Já não há.

Cliente: Mas, o meu filho comprou agora...

... é impossível, só pode estar louca!

vcass05 - (3) [41] tribunal

Advogada: Todos sabem que na noite do crime Ana Parsons estava em casa...

...a cuidar da mãe doente.

Exijo a liberdade da minha cliente 
Juíza: Existe algo que comprove este facto?

Nenhuma prova?

A suspeita será condenada.

Só você para achar que acreditei nessa história.

\section{Pronome você: relações simétricas}

vcsim01- [2] amigos no bar

Idoso: Quem quer cerveja?

Jovem 1: Albert... Ninguém vai beber aqui.

Estou a convencer a malta a ir a outro sítio.

Vamos para a Brown ou para a Wonk?

Vamos!

Jovem 2: A Brown fechou há que tempos!

Jovem 1: Ah, não!

Jovem 2: Foi você mesmo que nos disse.

vcsim02 - [5] casal discutindo

Homem: Eu vou-me embora.

Mulher: Faça como quiser.

Homem: Encontrei isto dentro da sua bolsa.

E então?

Vai continuar a negar que tem um caso?

Mulher: Não dá mais.

Não sou doente como você.

vcsim03 [5] conversando no carro

Mulher-jovem: Então, já vai?

Rapaz: É, amanhã tenho teste na Faculdade.

Preciso de estudar.

Mulher-jovem: A sério?

Rapaz: Não me olhe assim.

Sabe que eu tenho que estudar. Tem que perceber isso!

vcsim04 - [10] casamento

Noivo: $\mathrm{Na}$ alegria e na tristeza.

Na saúde e na doença.

Com todo o amor.

Noiva: Para compartilhar, respeitar e cuidar.

Com todos os meus defeitos

Você, ao meu lado... para sempre. (A2)

vcsim05 [14] conversa no trem

Moça: Da escola!

Da escola elementar Castelo... 
Encantado.

Rapaz: É uma que tinha a parede toda rabiscada.

Moça: Fui eu que rabisquei.

Rapaz: O quê?

Moça: Eu que rabisquei...

E os rapazes, inclusive você, levaram com a culpa.

\section{Frases distratoras: ruins (usos inadequados)}

\section{Distruim01 - 34-igreja}

Homem: Olá! Desculpe por entrar sem avisar.

Homem: Eu passei para fazer uma oração.

Homem: Já estou de saída.

Homem: Volto noutro dia.

Freira: Não existe hora certa para entrar na Casa do Senhor.

Todos podem entrar na Igreja...

Quando sentirem vontade.

Deus aprova, meu lindo

\section{Distruim02 - 38-pai e filho na trilha}

Filho: Caramba! Por que não me disse que a subida ia demorar tanto?

Pai: Já percorremos mais da metade, filho!

Estamos quase a chegar.

Filho: Estou cansado, pai.

Pai: Eu sei, mas é assim mesmo.

Agora não dá para voltar, temos que continuar.

Falta pouco agora.

Chega, eu quero voltar agora...velhote!

\section{distruim03 - 40-rapazes no trailer}

Rapaz 1: Por que isto está no chão? Coisas do meu pai de certeza.

Rapaz 2: Para que quer o teu pai esses frascos?

Rapaz 1: Sei lá, ele gosta de colecionar coisas velhas.

A família é louca, meu senhor.

\section{Distruim04 - 30-homens brigando basquete}

Homem 1: $\mathrm{O}$ que foi, parceiro?

Homem 2: Eu avisei que nunca mais os queria ver por aqui.

Mas acho que o recado não ficou muito claro.

Agora vou cumprir o que prometi.

Homem 1: E qual era a promessa?

Homem 2: É melhor não querer saber.

Homem 1: Eu até comprei-te um bolo. Vamos dividir.

\section{Disruim05 - 25-Criança-adolescentes}


Mocinha: Pai, está tudo bem consigo?

$\mathrm{O}$ que houve?

Criança: Este parvalhão tinha que aprender.

\section{Frases distratoras: boas}

\section{Distbom01 - 03-Briga em casa}

H1: O parvo aqui já sabe de tudo. Mentiroso!

$\mathrm{H} 2$ : O meu próprio irmão na cama com a minha mulher.

Eu já vi o vídeo. Traidor.

H2: Eu já disse que esse vídeo é montagem!

H1: Saia da minha frente agora!

\section{Distbom02 - 13-Casal-adolescente-entrevista}

Entrevistador: Onde é que os pombinhos se conheceram?

Garota: No colégio. E apaixonamo-nos.

Entrevistador: E o que tem ela de especial?

Garoto: Tudo. Ela é linda... E é muito inteligente.

E simpática.

Entrevistador: Sei... E por que ele?

Hum... Por tudo... Ele é muito giro também.

\section{Distbom03 - 07-Briga na cozinha}

Mulher: O que estás a fazer?

Homem: Estou a fazer uma tosta.

Mulher: E por que não me chamaste?

Não aguento mais isto.

Homem: Do que estás a falar?

Mulher: Deste nosso distanciamento.

Homem: Quem não está a aguentar sou eu...

Estamos a brigar por motivos tolos.

\section{Distbom04 - 09-Menina escrevendo}

Mocinha: Esse texto não me está a sair das mãos.

Rapaz: Porquê?

Mocinha: Não sei...

Leia.

Rapaz: Não

Mocinha: $\mathrm{O}$ quê?

Rapaz: Agora nós vamos lanchar.

\section{Distbom05 - 12-Conferência}

Promotora: Então, o senhor piloto afirma que não estava alcoolizado.

Piloto: Afirmo 
Aquela garrafa...

...não era minha.

Promotora: Não era sua...

Era de quem?

Piloto: A garrafa de vodka era da hospedeira de bordo.

\section{Cenas do treino:}

\section{Treino - 13-Casal na lanchonete}

Rapaz: Direito?

Desistiu de estudar Letras?

Mocinha: Letras é mais adequado ao meu perfil...

Mas os meus pais estiveram a conversar comigo.

E insistiram para eu fazer Direito.

Foi isso...

Rapaz: Porquê?

Mocinha: Porque Letras é uma carreira que não dá dinheiro.

\section{Treino-42-depoimento}

Promotor: Testemunhas a viram no local e na hora do assassinato!

Ré: Eu não fiz nada

Ré: Eu saí do trabalho mais cedo...

e fui para casa.

Promotor: Por que é que a senhora saiu mais cedo?

Ré: Que raio de pergunta é essa? Pronto, terminei o trabalho mais cedo. 